\title{
Modeling natural emissions in the Community Multiscale Air Quality (CMAQ) Model-I: building an emissions data base
}

\author{
S. N. Smith and S. F. Mueller \\ Tennessee Valley Authority, P.O. Box 1010, Muscle Shoals, Alabama, 35662-1010, USA \\ Received: 18 November 2009 - Published in Atmos. Chem. Phys. Discuss.: 21 January 2010 \\ Revised: 9 May 2010 - Accepted: 16 May 2010 - Published: 27 May 2010
}

\begin{abstract}
A natural emissions inventory for the continental United States and surrounding territories is needed in order to use the US Environmental Protection Agency Community Multiscale Air Quality (CMAQ) Model for simulating natural air quality. The CMAQ air modeling system (including the Sparse Matrix Operator Kernel Emissions (SMOKE) emissions processing system) currently estimates non-methane volatile organic compound (NMVOC) emissions from biogenic sources, nitrogen oxide $\left(\mathrm{NO}_{\mathrm{x}}\right)$ emissions from soils, ammonia from animals, several types of particulate and reactive gas emissions from fires, as well as sea salt emissions. However, there are several emission categories that are not commonly treated by the standard CMAQ Model system. Most notable among these are nitrogen oxide emissions from lightning, reduced sulfur emissions from oceans, geothermal features and other continental sources, windblown dust particulate, and reactive chlorine gas emissions linked with sea salt chloride. A review of past emissions modeling work and existing global emissions data bases provides information and data necessary for preparing a more complete natural emissions data base for CMAQ applications. A model-ready natural emissions data base is developed to complement the anthropogenic emissions inventory used by the VISTAS Regional Planning Organization in its work analyzing regional haze based on the year 2002. This new data base covers a modeling domain that includes the continental United States plus large portions of Canada, Mexico and surrounding oceans. Comparing July 2002 source data reveals that natural emissions account for $16 \%$ of total gaseous sulfur (sulfur dioxide, dimethylsulfide and hydrogen sulfide), $44 \%$ of total $\mathrm{NO}_{\mathrm{x}}, 80 \%$ of reactive carbonaceous gases (NMVOCs and carbon monoxide), $28 \%$
\end{abstract}

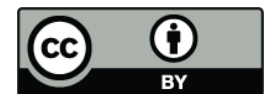

Correspondence to: S. N. Smith (snsmith@tva.gov) of ammonia, 96\% of total chlorine (hydrochloric acid, nitryl chloride and sea salt chloride), and $84 \%$ of fine particles (i.e., those smaller than $2.5 \mu \mathrm{m}$ in size) released into the atmosphere. The seasonality and relative importance of the various natural emissions categories are described.

\section{Introduction}

Air quality modeling as practiced in the United States is often done to support air pollution management decisions that result in controls on anthropogenic pollutant sources. If the goal of this work involves secondary pollutants such as ozone or fine particles, or is regional in scope, then the air quality models that are used are typically those that include sophisticated descriptions of relevant chemical and physical processes. A major effort is required to develop emissions inputs to these models. Much of the effort involves detailed information about anthropogenic sources which are either treated individually (as so-called "point" sources) or collectively (and referred to as "area" sources; this can include "non-road" and "mobile" type sources as well). Natural emissions of biogenically produced gases or physically generated particles are also included to the extent that such emissions are considered important for the air management problem under consideration. There are several categories of natural emissions that are currently not assimilated into many regional air quality models. The reasons for this are usually associated with expectations that such emissions are not important when compared to anthropogenic emissions, or the emissions processes themselves are complex and not as well characterized as emissions that are typically modeled.

There are disadvantages to neglecting certain classes of emissions as reported by Chameides et al. (1988), Novak and Pierce (1993), DeCaria et al. (2000), Guenther et

Published by Copernicus Publications on behalf of the European Geosciences Union. 
al. (2000), Tonnesen et al. (2006), Kaynak et al. (2008), Koo et al. (2010) and others. First, neglected emissions may, at some times and in some places, play significant roles in the photochemical evolution of the atmosphere even in the presence of anthropogenic emissions. Neglecting these emissions does not mean that they are always unimportant. Second, neglected emissions become increasingly important contributors to background levels of certain pollutants as anthropogenic emissions decrease. An air management strategy may overestimate improvements in air quality in the face of neglected emission components.

This paper describes the first part of an effort to incorporate a greater diversity of natural emissions into an air quality model that is widely used for air management studies. The effort starts by casting a wider net for emissions sources and types. The results of this work are subsequently described and the resulting natural emission components are compared with anthropogenic emissions for the same time period. Later papers will describe changes to an air quality model necessitated by the introduction of new emission sources and simulation results from that model.

\section{Previous work}

Much of the effort to characterize air pollutant emissions has focused on anthropogenic sources of sulfur, nitrogen oxides, and non-methane volatile organic compounds (henceforth referred to as VOC). This paper will not dwell on these sources other than to compare natural and anthropogenic emissions in Sect. 5. Note that the US Environmental Protection Agency (EPA) has an ongoing effort to characterize and quantify US man-made emissions (http://www.epa.gov/ oar/oaqps/emissns.html). The National Acid Precipitation Assessment Program (NAPAP, 1991) conducted one of the earliest comprehensive efforts to quantify and compare anthropogenic and natural sources of emissions that influence ozone, acid deposition and haze (i.e., fine particles). That work still influences air quality modeling today.

\subsection{Background}

The NAPAP (1991) reported that primary natural sources of sulfur were the oceans (principally dimethylsulfide, DMS), trees (especially carbonyl sulfide, COS), soils (DMS, $\mathrm{H}_{2} \mathrm{~S}$ ), crops (COS), and wetlands $\left(\mathrm{H}_{2} \mathrm{~S}, \mathrm{COS}\right.$, and DMS). Emissions of $\mathrm{SO}_{2}$ from volcanoes are usually sporadic and unpredictable. Emission rates for $\mathrm{H}_{2} \mathrm{~S}$ from hot springs and fumaroles (thermal vents), though small, become significant in regions where geothermal activity is high such as in Yellowstone National Park, the home to about half of the world's geysers (W. C. Evans, US Geological Survey, personal communication, 2005). The largest uncertainties - a factor of three according to NAPAP - are in soil and tree sulfur emissions. This is due to the variety of sulfur species and in- dependent factors (i.e., meteorological, vegetation and soil type) influencing emissions, and a general lack of field data. Using data from NAPAP (1991), one can estimate that marine emissions of DMS from waters within $500 \mathrm{~km}$ of the US coastline average about $1400 \mathrm{Mg}$ of $\mathrm{S}$ per annum (MgSa). Compare this with estimated annual emissions of DMS $+\mathrm{H}_{2} \mathrm{~S}$ from soils (3200 MgSa) and trees (2200 MgSa) within the continental US. Emission rates of reduced sulfur from terrestrial waters (freshwater lakes, wetlands) can also be significant but their surface coverage is very small. Finlayson-Pitts and Pitts (2000) downplay the importance of COS oxidation in the atmosphere due to its extremely slow reactivity with $\mathrm{OH}$. Thus, our natural sulfur emissions modeling focused on DMS, $\mathrm{H}_{2} \mathrm{~S}$, and $\mathrm{SO}_{2}$.

Research by Wang et al. (1998), Guenther et al. (2000) and others has shown that the major natural sources of $\mathrm{NO}_{\mathrm{x}}$ $\left(\mathrm{NO}+\mathrm{NO}_{2}\right)$ include lightning, soils, and biomass burning. Ocean emissions make a considerable contribution to the global natural nitrous oxide budget. According to Denman et al. (2007), natural ocean emissions comprise $35 \%$ of the total global natural source of $\mathrm{N}_{2} \mathrm{O}$. Though this source is substantial it is believed to have a relatively minor impact on tropospheric chemistry (Finlayson-Pitts and Pitts, 2000). The NAPAP estimated $\mathrm{NO}_{\mathrm{x}}$ production from lightning over North America as $1.2 \times 10^{6} \mathrm{Mg}$ of $\mathrm{NO}_{2}$ equivalent per year with the highest emissions occurring over the southern US in summer. Guenther et al. (2000) provides an estimate of $2.9 \times 10^{6} \mathrm{Mg}$ of $\mathrm{NO}_{2}$ equivalent per year from lightning in North America. Soil $\mathrm{NO}_{\mathrm{x}}$ emissions depend primarily on four factors: soil moisture, vegetation cover, nutrient level and temperature. Estimates are made by scaling up from land cover type and applying measured emission fluxes adjusted for soil moisture and temperature. Continental US soil $\mathrm{NO}_{\mathrm{x}}$ emissions have been estimated in the range of $0.4-3.6 \times 10^{6} \mathrm{Mg}$ of $\mathrm{NO}_{2}$ equivalent per year (NAPAP, 1991). Compare this range to $1.4 \times 10^{6} \mathrm{Mg}$ of $\mathrm{NO}_{2}$ equivalent estimated by Guenther et al. (2000) for continental US soils.

Biomass burning in the US is primarily from wildfires although agricultural fires for land clearing also occur. According to the National Interagency Fire Center (http://www. nifc.gov/fire_info/lightning_human_fires.html), the portion of wildfires caused by lightning ranged from about $11 \%$ to around $20 \%$ in the 2001-2008 timeframe with the remaining contribution considered induced by human activity. For our natural source emissions modeling purposes we focus on wildfire emissions understanding that human activity is still involved in many of these "wild" fires. Wildfires emit $\mathrm{NO}_{\mathrm{x}}$ along with $\mathrm{CO}, \mathrm{NH}_{3}, \mathrm{VOCs}, \mathrm{SO}_{2}$ and fine particles. Fuel (vegetation) type, fuel moisture content, wind speed, topography, and fire type and size (area burned) all influence fuel consumption and emissions. Techniques for estimating wildfire emissions were summarized by Battye and Battye (2002) for the US EPA. From this report, the average emissions as a function of the mass of fuel burned are, by pollutant $(\mathrm{kg}$ emitted per $10^{3} \mathrm{~kg}$ burned): $144(\mathrm{CO}), 6.8\left(\mathrm{CH}_{4}\right), 3.1\left(\mathrm{NO}_{\mathrm{x}}\right.$ 
expressed as $\left.\mathrm{NO}_{2}\right), 6.8$ (VOC carbon), $0.8\left(\mathrm{SO}_{2}\right), 0.6\left(\mathrm{NH}_{3}\right)$, and $12\left(\mathrm{PM}_{2.5}\right)$. The NAPAP did not estimate US emissions from fires. In recent years, detailed records of wildfires by the US Forest Service have improved the data base on wildfires and presumably increased the accuracy of fire emission estimates for air quality modeling. A key technology assisting in this wildfire inventory improvement is the SMARTFIRE (Satellite Mapping Automatic Reanalysis Tool for Fire Incident Reconciliation) system, an online system developed by a collaboration of researchers including the US Forest Service, the EPA, and Sonoma Technology, Inc. (and others). The SMARTFIRE system is designed to reconcile ground reports of fire burn information with satellite-detected fires to enhance spatiotemporal resolution and detection efficiency of fires. More information on SMARTFIRE is available at http://www.getbluesky.org.

Natural emissions of VOCs are almost completely associated with biogenic sources and wildfires. Vegetation emissions of various hydrocarbons have long been considered an integral component of ozone photochemistry. Sillman (1999) and others estimate that US summer biogenic emissions of hydrocarbons equal or exceed anthropogenic hydrocarbon emissions. Much biogenic VOC emissions data were collected during the 1980s and the NAPAP (1991) summarized emission rates derived from that work, including an estimate of about $27 \times 10^{6} \mathrm{Mg}$ of $\mathrm{C}$ per year for the continental US. These VOC rates are especially important given the high reactivity of isoprene, the predominant biogenic VOC species ( $27 \%$ of the total in the NAPAP estimate), emitted by hardwood trees (Kinnee et al., 1997). Guenther et al. (2000) estimated about $42.8 \times 10^{6} \mathrm{Mg}$ of $\mathrm{C}$ annually for continental US VOC with about $36 \%$ of this total attributed to isoprene.

Although wildfires are the largest natural source of primary $\mathrm{PM}_{2.5}$ emissions, two other sources of note are windblown dust and sea salt. Dust, usually composed primarily of weathered minerals such as carbonates, silicates and metal oxides, is produced when wind erodes exposed, dry soils. Soil particles are often lofted higher into the air through the action of convective turbulence and dust devils. Surface flux of windblown dust is controlled by soil type, vegetation cover, soil moisture and wind speed. For the purposes of this study fugitive dust produced from vehicles on unpaved roads and dust generated by agricultural tillage are considered to have anthropogenic origin and are therefore not considered a truly natural source of windblown dust. However, these components are often estimated for Regional Planning Organization (RPO) modeling inventories and the EPA National Emissions Inventory (NEI). NAPAP (1991) estimated the total US emission of alkaline soil dust (including roads) at about $19 \times 10^{6} \mathrm{Mg} \mathrm{yr}^{-1}$. Emission estimates for these fugitive dust sources are considered to have high uncertainty.

Sea salt is generated by the action of wind blowing over the ocean, generating waves and promoting the formation of bubbles (from trapped air) and spray from breaking waves. Small droplets are produced from spray and as bubbles burst upon reaching the surface. Evaporating droplets leave behind salt particles composed primarily of chlorides. Athanasopoulou et al. (2008) reviewed past efforts at estimating sea salt particle fluxes and applications to atmospheric modeling. They opted to use the methodology of Clarke et al. (2006) as extended to smaller particle sizes by Gong (2003) for open ocean sea salt aerosol (SSA) production. In addition, they used the methodology by De Leeuw et al. (2000) for estimating SSA flux in surf zones. Both methodologies estimate size-dependent SSA flux as a function of $10-\mathrm{m}$ wind speed, correcting for the effect of relative humidity on SSA diameter. Athanasopoulou et al. (2008) input data from both flux methods to the CAMx air quality model (ENVIRON, 2004) to examine SSA transport and chemical evolution over the Greek archipelago. They concluded that their selected methodologies for estimating SSA flux produced realistic results for SSA over land, with the contribution to total $\mathrm{PM}_{10}$ (60\% maximum) and $\mathrm{PM}_{2.5}$ (10\% maximum) dropping rapidly with distance from the coast.

\subsection{Natural emissions in the EPA CMAQ model}

One widely used air quality simulation tool, originally developed by the US EPA, is the Community Multiscale Air Quality (CMAQ) Model (Byun and Schere, 2006). Currently, the treatment of natural emissions in CMAQ includes the following: biogenic sources (i.e. vegetation and soil), windblown dust (via special treatment with modules external to the CMAQ system), wildfires, and sea salt. The Sparse Matrix Operator Kernel Emissions (SMOKE) modeling system (CMAS, 2008) is a data preprocessor that provides emissions input files for CMAQ and other air quality models. For biogenic sources SMOKE produces VOC emissions from vegetation and $\mathrm{NO}$ emissions from soil based on land coverspecific emissions factors and meteorology. Enhancements to windblown dust emissions modeling have recently been introduced such as the development of a windblown dust model for the Western Regional Air Partnership Regional Planning Organization (WRAP) RPO produced by ENVIRON International Corporation (Mansell et al., 2006) that allows treatment of dust emissions based on meteorology and soil/landscape cover offering improvements over the more generalized estimates typically found in emissions inventory development.

Traditionally, SMOKE treats wildfire emissions as lowlevel area sources. However, recent RPO inventories have been developed to provide daily fire emissions from point source wildfires along with hourly plume rise for vertical allocation of their emissions. SMOKE has also been adjusted to handle other fire-specific characteristics such as fuel loading and fire burn area (http://www.smoke-model.org).

Beginning with CMAQ version 4.5 , a new aerosol module was included to perform calculations of sea salt emissions from open oceans. This module produces emissions as a function of wind speed and relative humidity (http: 
//www.cmaq-model.org). Prior to this version of CMAQ, sea salt - if included at all - was only handled separately outside the model. Such an approach required a special model to produce emission estimates.

\subsection{Global emissions}

An emerging modeling system suitable for both global and regional simulation of air emissions from terrestrial ecosystems is the MEGAN (Model of Emissions of Gases and Aerosols from Nature) system (http://acd.ucar.edu/ $\sim$ guenther/MEGAN/MEGAN.htm). MEGAN is designed to be a replacement to the EPA Biogenic Emissions Inventory System (BEIS) modeling system and has been used in a number of recent studies investigating VOC flux from vegetation including Guenther et al. (2006), Helmig et al. (2007), Sakulyanontvittaya et al. (2008) and others. Two examples of global atmospheric chemistry models are the GEOS-Chem (http://acmg.seas.harvard.edu/geos/index.html) and the GOCART models (http://data.eol.ucar.edu/codiac_data/ace-asia/ docs/model_chem_GO-CART.html). These models have been used by Park et al. (2004, 2006), Chin et al. (2002), the US RPOs and others in research that incorporated natural emission source influences. Common emissions inventories employed by these global models include the GEIA, EDGAR, and POET databases. Natural source emissions provided in the GEIA (Global Emissions Inventory Activity) data set or from GEIA-affiliated data sets include releases from soils, biomass burning, animals, oceans, volcanoes, vegetation, and lightning. Further information on the GEIA emissions inventories is available from http://www. geiacenter.org.

Other examples of global emissions inventories for natural sources include the POET (http://www.aero.jussieu.fr/ projet/ACCENT/POET.php) and EDGAR (http://www.mnp. nl/edgar/) global data sets. Natural source emissions from POET include global emissions estimates for ozone precursor gases from biogenic and oceanic sources (Granier et al., 2005). EDGAR provides natural emission estimates for $\mathrm{N}_{2} \mathrm{O}$ from soils, grasslands, and oceans/wetlands; non-methane VOCs from natural vegetation; $\mathrm{CH}_{4}$ from soils, grasslands, natural vegetation, and oceans/wetlands; $\mathrm{NH}_{3}$ from wild animals, soils, and oceans; $\mathrm{NO}_{\mathrm{x}}$ from soils and lightning; and $\mathrm{CO}$ from vegetation and oceans/wetlands (Olivier et al., 2002). Uncertainty estimates for these natural emissions range from 50 to $100 \%$ (Olivier et al., 2002).

There are numerous examples of previous continental to global scale air quality modeling that have incorporated these global emissions data sources. Park et al. (2003) - focusing on background levels of organic carbon (OC) and elemental carbon (EC) particles over the United States - used an inventory of global anthropogenic OC and EC emissions developed by Cooke et al. (1999) for 1984 and modified for their 1995 and 1998 simulations. While simulating sulfate and nitrate aerosol, Park et al. (2004) utilized global fossil fuel and industrial emissions from the GEIA data base as described by Benkovitz et al. (1996). Marine emissions of DMS were calculated from monthly gridded seawater concentrations from Kettle et al. (1999). Park et al. (2004) also used ammonia emissions from the GEIA inventory of Bouwman et al. (1997). The EDGAR inventory was used by Sudo et al. (2002) to model global air quality with the CHASER model. They also obtained ocean emissions from Müller (1992) and biomass burning data from Hao and Piu (1994).

A common feature of all these inventories is their coarse spatial resolution. This is not necessarily bad given their use in global models but it does present some challenges if they are used in higher resolution models. Ongoing efforts to examine natural emissions impacts over the continental US requires emissions primarily from North America and surrounding oceans. Outside this area model boundary conditions must be derived from outputs from global models that use coarsely-resolved global emissions and will have a minor influence on results for the continental US. The widespread acceptance and ease of access to the GEIA data base makes it highly attractive for model applications.

\section{Adding natural emissions to the CMAQ Model}

The CMAQ Model was selected for use in an ongoing study of the role of natural emissions in US air quality. Recently, CMAQ input emissions files for 2002 were prepared to simulate aerosols (Tesche et al., 2006). These files include detailed anthropogenic sources, biogenic sources of VOCs and $\mathrm{NO}_{\mathrm{x}}$, windblown dust, and wildfires (MACTEC, 2008). Methods and data bases used to add other natural emissions to those already prepared for 2002 are described below.

\subsection{Lightning $\mathrm{NO}_{\mathrm{x}}$}

Emissions of $\mathrm{NO}_{\mathrm{x}}$ from lightning discharges have been included in a number of air quality modeling exercises, including Novak and Pierce (1993), Sudo et al. (2002), Park et al. (2004), Heald et al. (2006), Kaminski et al. (2007) and others. $\mathrm{NO}_{\mathrm{x}}$ from lightning represents a significant portion of the annual $\mathrm{NO}_{\mathrm{x}}$ emissions budget, with estimates of between 5 and $11 \%$ in the studies just cited. The effects of lightning $\mathrm{NO}_{\mathrm{x}}$ can be local - from cloud-to-ground discharges that inject $\mathrm{NO}_{\mathrm{x}}$ directly into the boundary layer - and regional due to the long-range transport of lightning $\mathrm{NO}_{\mathrm{x}}$ discharged into the upper troposphere. This is one source of $\mathrm{NO}_{\mathrm{x}}$ that has traditionally not been treated in regional simulations using CMAQ and its emissions processing system SMOKE.

Recently, much effort has gone into developing methods to estimate $\mathrm{NO}_{\mathrm{x}}$ produced by lightning. One approach is to use a satellite optical detector to estimate the occurrence of lightning flashes (Nesbitt et al., 2000). From this one can estimate $\mathrm{LNO}_{\mathrm{x}}$ by assuming a per-flash $\mathrm{NO}_{\mathrm{x}}$ production rate. The method suffers from incomplete global coverage and 
low detector sensitivity, as well as the usual problems associated with estimating the ratios of cloud-to-ground (CG) to intra-cloud (IC) flashes and the vertical distribution of $\mathrm{LNO}_{\mathrm{x}}$. Another method uses cloud information such as convective cloud occurrence and top height generated by a meteorological model and then assumes flash rates, vertical distributions and $\mathrm{NO}_{\mathrm{x}}$ formation rates associated with the simulated convection (Pickering et al, 2006). The US National Aeronautics and Space Administration (NASA) is experimenting with using remote sensing of atmospheric chemical signatures to estimate lightning $\mathrm{NO}_{\mathrm{x}}$ for use in real-time air quality forecasting (http://nasascience.nasa.gov/earth-science/ applied-sciences/resources/CMAQr1.pdf). The method used here is very similar to that of Kaynak et al. (2008) who used lightning flash data from the National Lightning Detection Network (NLDN). Kaynak et al. (2008) horizontally allocated lightning-derived $\mathrm{NO}_{\mathrm{x}}$ based on whether clouds were simulated to occur in the CMAQ model grid cell associated with the measured lightning flash or in adjacent cells whenever no clouds were simulated in the flash cell. The latter occurrence was very rare $(<1.5 \%$ at most). Vertical allocation of emissions was based on published lightning profiles and modeled cloud top heights. Kaynak et al. (2008) made CMAQ model simulations for July-August 2004 with and without lightning $\mathrm{NO}_{\mathrm{x}}$ and found that lightning could contribute significantly to ground level ozone in some circumstances. Another recent study that also determined that lightning could contribute significantly to ozone levels, particularly in the southeastern US, is the work performed by Koo et al. (2010). Koo et al. (2010) simulated lightning NO assuming a static emission rate of $9.3 \mathrm{Kg} \mathrm{N}$ per CG flash from Holler and Schumann (2000). Koo et al. (2010) assumed 30 million flashes per year for North America from Orville et al. (2002) then applied a multiplier of 2.8 IC flashes per CG flash from Boccippio et al. (2001) resulting in NO simulation for 114 million flashes. Koo et al. (2010) then used hourly convective precipitation, cloud depth, and pressure to make spatiotemporal allocations of these lightning emissions.

In the present work 2002 NLDN flash data were acquired for the CMAQ modeling domain (see the Appendix A). Rather than simply applying an assumed static factor for flash emissions rates as has been done elsewhere, the emissions rates for flashes in the 2002 simulation used an algorithm to estimate flash-specific emissions rates. This approach, referred to as the mean peak current method, is a variation on the methods described by Price et al. (1997), DeCaria et al. (2000), and Ott et al. (2010). The basis of this approach is CG flash data from the NLDN data set. We introduce separate treatment of positive flash return strokes and use all NLDN peak current values (rather than setting a minimum threshold) as recorded in the data set. Details of calculations used to estimate $\mathrm{LNO}_{\mathrm{x}}$ emissions are summarized in the Appendix A. The vertical allocation of $\mathrm{LNO}_{\mathrm{x}}$ was not tied to simulated cloud top heights but was instead fixed. This assumption seems reasonable given the unknown

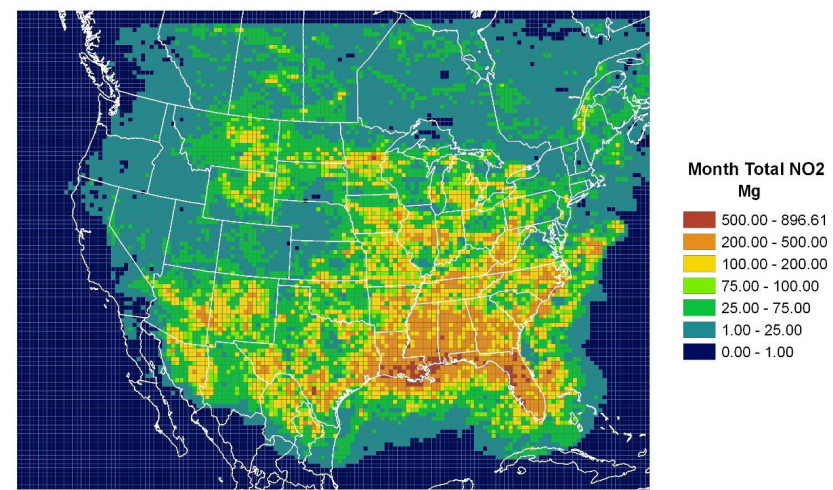

Fig. 1. Total lightning $\mathrm{NO}_{\mathrm{x}}$ emissions $\left(\mathrm{Mg}\right.$ of $\left.\mathrm{NO}_{2}\right)$ calculated for July 2002 across the atmospheric modeling domain derived from NLDN data.

and suspected limited skill of the meteorological model to accurately estimate convective cloud top heights for $36 \mathrm{~km}$ grid cells. The resulting spatial distribution of $\mathrm{LNO}_{\mathrm{x}}$ emissions at the time of the expected summer peak is shown in Fig. 1.

\subsection{Reduced sulfur}

Globally, reduced sulfur emissions from the oceans represent at least $20 \%$ of the total sulfur budget (Park et al., 2004). Reduced sulfur occurs primarily in the form of DMS but may also exist as $\mathrm{H}_{2} \mathrm{~S}, \mathrm{COS}$, dimethyldisulfide, carbon disulfide and methyl mercaptan (Finlayson-Pitts and Pitts, 2000). Over the oceans DMS emissions are an important source of marine aerosols (Kreidenweis et al., 1991). DMS and $\mathrm{H}_{2} \mathrm{~S}$ are both significant over land - especially from soils, certain vegetation and surface waters - jointly accounting for over half of total reduced sulfur emissions in the US (NAPAP, 1991). The balance of naturally emitted sulfur is mostly as COS, a relatively slow-reacting compound (Finlayson-Pitts and Pitts, 2000). Natural sulfur sources are small in magnitude compared to anthropogenic sources of $\mathrm{SO}_{2}$ (NAPAP, 1991; Finlayson-Pitts and Pitts, 2000; Park et al., 2004) but may become important, in the absence of significant $\mathrm{SO}_{2}$, as a source of atmospheric sulfate.

\subsubsection{Oceans}

Ocean DMS emissions were taken from the annual mean flux of sulfur from the oceans as delineated by Kloster et al. (2006). Monthly emissions were produced using the ocean DMS temporal profile shown in the Appendix A. This monthly profile derives from the work of Kettle and Andreae (2000). Kloster et al. (2006) stated that their ocean DMS results were in good agreement with the work performed by Kettle and Andreae (2000). Hourly ocean DMS emissions were produced for a representative day using the SMOKE 
default temporal profile for natural sources also shown in the Appendix A.

Estimated ocean $\mathrm{H}_{2} \mathrm{~S}$ flux utilized the emissions factor (see Appendix A) recommended by Andreae and Jaeschke (1992). Given the limited and varying information available on marine $\mathrm{H}_{2} \mathrm{~S}$ temporal variations, we decided to simply allocate the emissions using the factor from Andreae and Jaeschke (1992) into a single representative day with equal allocation of the emissions into each hour of the day. Further refinement of this method may be appropriate for future modeling of this source.

\subsubsection{Coastal wetlands}

Sulfur emission factors applied in this modeling for coastal wetlands (as shown in the Appendix A) are an average of the results from a number of studies on sulfur flux from salt marsh and Spartina Alterniflora including Steudler et al. (1985), Giblin and Wieder (1992), and DeLaune et al. (2002). According to the US Department of Agriculture (http://plants.usda.gov/), Spartina Alterniflora distributions are found in twenty US coastal states and along the eastern coastlines of Canada. Significant distributions of Spartina Alterniflora are not found along the west coast of Canada and it is not native to Mexico nor were there any area distributions for this grass readily available for Mexico. A number of land cover datasets were used to select coastal areas of land cover classes relevant to existing wetland sulfur emission factors. These land cover datasets included US NLCD (National Land Cover Database) for 1992 and 2001, GAP land cover (for Florida only), and land cover from the NOAA Coastal Services Center. More recent NLCD datasets were not available for many areas during this project. For more information and access to these datasets visit http://www.epa.gov/mrlc/. Emissions were produced for a single representative day using the SMOKE default natural source temporal profile (see Appendix A). Incorporating monthly/seasonal variability to these emissions should be explored for future work.

\subsubsection{Freshwater}

Emission factors applied here for $\mathrm{H}_{2} \mathrm{~S}$ and DMS from freshwater lakes (see Appendix A) in Canada were selected by taking values from the lower range of freshwater sulfur flux estimates derived from several studies including Richards et al. (1991), Bates et al. (1992), Giblin and Wieder (1992), Gröne (1997), Bodenbender et al. (1999), and Sharma et al. (1999). A representative day of $\mathrm{H}_{2} \mathrm{~S}$ and DMS emissions was created from these emission factors and the SMOKE default temporal profile for natural sources. This representative day was then assumed for all remaining days of the ice-free season (i.e. April-November following Sharma et al., 1999).

Sulfur emissions for the Great Lakes were estimated for a representative day using the same $\mathrm{H}_{2} \mathrm{~S}$ and DMS emissions and temporal factors that were applied for the afore- mentioned Canadian interior freshwater lakes. However, no frozen lake periods were assumed because of the small fraction (no more than approximately $11 \%$ ice cover for all lakes combined in the Great Lakes for 2002; see http://www.glerl. noaa.gov/data/ice/atlas/) of total surface area covered by winter ice.

\subsubsection{Other sources}

Other natural sources of reduced sulfur that were modeled include the Great Salt Lake (GSL), soils, and geothermal sources such as volcanoes and fumaroles. Given the lack of available information on natural atmospheric emissions from the GSL, it was decided to apply DMS emissions factors for Canadian interior lakes similar in composition to the GSL. Comparisons were made to lakes described in Richards et al. (1994). Patience Lake located in southern Saskatchewan was the closest match in composition to the GSL (assuming seawater as the closest proxy to the GSL). Fluxes of DMS were created using the mean DMS flux for Patience Lake as given in Richards et al. (1994). The $\mathrm{H}_{2} \mathrm{~S}$ emissions factors for GSL were more problematic. Because no data were available, the same $\mathrm{H}_{2} \mathrm{~S}$ emission factor used for the Great Lakes was applied to the GSL. A freshwater $\mathrm{H}_{2} \mathrm{~S}$ factor should be very conservative when applied to the GSL. A representative day of DMS and $\mathrm{H}_{2} \mathrm{~S}$ emissions were created using the same natural source temporal allocation profile used for other species. Emissions factors used for the GSL are shown in the Appendix A.

We estimated reduced sulfur emission from soils based on the ratio of soil $\mathrm{NO}_{\mathrm{x}}$ and reduced sulfur (DMS and $\mathrm{H}_{2} \mathrm{~S}$ ) budgets estimated by NAPAP (1991). The resulting conversion factors for $\mathrm{H}_{2} \mathrm{~S}$ and DMS were then directly applied to the SMOKE v2.5 BEIS3.14 processor results for soil nitric oxide (used as a modeled spatial surrogate) to estimate reduced sulfur fluxes.

Geothermal fluxes of natural sulfur emissions including volcanoes, fumaroles and hot springs were also simulated. Geothermal sources and emissions factors simulated here are shown in the Appendix A. Selection of volcanoes for this modeling was based on the availability of source-specific emissions factors. Though Mexico contains four major volcanoes none of them are found in our modeling domain, thus, only other Mexican geothermal features were included. Likewise, in Canada only non-volcanic geothermal features were included in the modeling domain. The SMOKE default natural source temporal profile was used to produce a representative day of emissions for geothermal $\mathrm{SO}_{2}$ and $\mathrm{H}_{2} \mathrm{~S}$.

\subsection{Ammonia}

Ammonia plays two important roles in the evolution of natural air quality. Its alkalinity affects the $\mathrm{pH}$ balance of cloud droplets and droplet acidity influences various chemical reaction rates (National Research Council, 1983). Ammonia 
gas reacts with nitric acid in the presence of water to produce ammonium nitrate aerosols (Finlayson-Pitts and Pitts, 2000). The natural sources of ammonia included in this simulation were oceans, wild animals, and wildfires. Wildfires are not discussed here as they are detailed further in Sect. 3.5. It is important to note that while native soils are considered a viable natural source of atmospheric $\mathrm{NH}_{3}$ (about $17 \%$ of the natural $\mathrm{NH}_{3}$ total emissions for the contiguous US in 2001 according to Park et al., 2004) soil $\mathrm{NH}_{3}$ emissions are also difficult to quantify because soils can both emit and absorb ammonia (NAPAP, 1991). This creates ambiguity over whether soils are a net sink or source of ammonia. Therefore, soil $\mathrm{NH}_{3}$ was not included in the current natural emissions modeling inventory. ${ }^{1}$

The method applied here for modeling natural emissions of $\mathrm{NH}_{3}$ from wild animals was based on the work described by Mansell (2005). The Carnegie Mellon University (CMU) Ammonia Model version 3.6 (Davidson et al., 2004) was used to estimate the annual total wild animal (i.e. bear, deer, and elk) $\mathrm{NH}_{3}$ emissions from the contiguous US (emissions factors shown in the Appendix A). These wild animal emissions were considered temporally invariant consistent with both Davidson et al. (2004) and Mansell (2005). Annual emissions were subsequently converted to a representative day with no hourly variation. The wild animal $\mathrm{NH}_{3}$ emissions for Canada were also estimated using the CMU factors. These factors were applied to activity data acquired (where available) from government environmental agencies for each Canadian province in the modeling domain. Additionally, Canadian populations (i.e. activity) of moose were also incorporated. The CMU emission factor for elk was used as a surrogate for moose. The same type of temporally invariant representative day of emissions as created for wild animals in the US was also created for Canadian wild animals. Given the limited information on wild animal populations within Mexico, we decided to use the GEIA wild animal $\mathrm{NH}_{3}$ emissions data set in our emission inventory. Annual totals from the GEIA data base were handled in a similar fashion as performed in our work for US wild animal emissions.

Annual emissions estimates of natural $\mathrm{NH}_{3}$ from oceans were taken from the GEIA database and once again the default SMOKE natural source temporal profile was used to create a temporally invariant representative day of ocean $\mathrm{NH}_{3}$. Further research on the temporal allocation of ocean $\mathrm{NH}_{3}$ emissions for the refinement of default temporal profiles used in this simulation is needed.

\subsection{Chlorine}

Atmospheric chlorine is very reactive in its various forms. Reactive $\mathrm{Cl}_{2}$ photolyzes into atomic $\mathrm{Cl}$, which further reacts with many substances, including VOCs, DMS, and $\mathrm{H}_{2} \mathrm{~S}$.

\footnotetext{
${ }^{1}$ Ammonia emissions from fertilized agricultural soils are considered to be an anthropogenic source.
}

Many of these reactions were included in the revised CMAQ CBIV gas chemical mechanism starting with version 4.5 (http://www.cmascenter.org) and were based on the work of Tanaka et al. (2003a). Reaction of $\mathrm{Cl}$ with $\mathrm{O}_{3}$ produces $\mathrm{ClO}$ which in turn reacts with $\mathrm{HO}_{2}$ to produce $\mathrm{HOCl}$ (Atkinson et al., 2007). Furthermore, $\mathrm{HOCl}$ photolyzes to produce $\mathrm{Cl}$ and $\mathrm{OH}$. Thus, in coastal areas where natural chlorine is most abundant it can play an important role in photochemistry (Knipping and Dabdub, 2003). In addition, hydrochloric acid is readily absorbed into cloud droplets, influencing $\mathrm{pH}$ and aqueous reactions.

Aside from volcanic emissions of $\mathrm{HCl}$, the primary source of natural chlorine is sea salt dechlorination by $\mathrm{N}_{2} \mathrm{O}_{5}$ (Behnke et al., 1997). This process yields $\mathrm{ClNO}_{2}$ that photolyzes to release $\mathrm{Cl}$ or reacts with $\mathrm{OH}$ in the gas phase to form $\mathrm{HOCl}$ (Atkinson et al., 2007). Simulating the reaction of $\mathrm{N}_{2} \mathrm{O}_{5}$ with sea salt in an air quality model requires modifications to the model's physical/chemical aerosol module in order to accurately capture the relationship between gases and particles. The current study does not attempt modifications to the CMAQ aerosol module. Instead, $\mathrm{ClNO}_{2}$ is incorporated into CMAQ by adding estimates of equivalent nearsurface $\mathrm{ClNO}_{2}$ flux as a surrogate for complex gas-aerosol interactions.

Natural sources of chlorine emissions estimated for our 2002 inventory include sea salt aerosols (fine and coarse chloride) and gaseous $\mathrm{HCl}$ and $\mathrm{ClNO}_{2}$ from the oceans. Annual totals of $\mathrm{HCl}$ and $\mathrm{ClNO}_{2}$ from oceans were taken from the GEIA Reactive Chlorine Emissions Inventory (RCEI) (Erickson et al., 1999). Monthly totals were derived from factors in Erickson et al. (1999). These factors produce lower emissions in the summer months and peaks in the winter. The GEIA $\mathrm{CINO}_{2}$ fluxes for the ocean waters around North America were modified to reflect the fact that they include the influences of both natural and anthropogenic $\mathrm{NO}_{\mathrm{x}}$ emissions. This was done by determining the ratio of natural to anthropogenic $\mathrm{NO}_{\mathrm{x}}$ over land near the oceans and then partitioning the GEIA $\mathrm{CINO}_{2}$ fluxes proportionately into natural and anthropogenic components. This produced a much lower estimate of natural $\mathrm{ClNO}_{2}$ flux than would otherwise have been estimated and avoided the introduction of artificially high $\mathrm{NO}_{2}$ levels over the oceans once daytime $\mathrm{ClNO}_{2}$ reacts with $\mathrm{OH}$ to liberate $\mathrm{NO}_{2}$. Monthly natural weighting factors calculated ranged from 12 to $17 \%$ (denoting subtle seasonal variations for the split) with the remaining 83 to $88 \%$ assigned as the monthly anthropogenic weighting factors. A representative day of emissions for each month was subsequently created with hourly allocations based on Keene et al. (2007) and Osthoff et al. (2008). Temporal profiles applied for $\mathrm{HCl}$ and $\mathrm{ClNO}_{2}$ are shown in the Appendix A. 


\subsection{Wildfires}

Wildfire emissions have been traditionally treated as stationary area sources. However, this has changed such that wildfire emissions are now treated as point sources with enhanced temporal modeling including day-specific emissions and hourly plume rise (http://www.smoke-model.org/ version2.5). Fortunately, the intricacies of handling fire records for inclusion in air quality modeling were already performed for 2002 by the various RPOs. The appropriate fire records were identified in the RPO inventories using the source classification code (SCC) for wildfires and by assuming all other fires to be anthropogenic. Canada wildfires were selected as available from the 2002 MARAMA (MidAtlantic Regional Air Management Association) and Environment Canada 2000 inventories while Mexico wildfires were selected from Phase III of the 1999 Mexico National Emissions Inventory (NEI). The US, Canadian and Mexican wildfire inventories were subsequently processed with SMOKE. Area source fires were processed for representative days while point source fires were processed for each day of the episode to utilize daily meteorology (needed for plume rise calculations). This approach closely mimics the method applied for the VISTAS RPO 2002 simulations described in Morris et al. (2004). Pollutants produced from wildfires in our modeling included VOCs, $\mathrm{CO}, \mathrm{NH}_{3}, \mathrm{NO}_{\mathrm{x}}, \mathrm{SO}_{2}, \mathrm{PM}_{c}$, unspeciated $\mathrm{PM}_{2.5}$ and fine particulate $\mathrm{EC}$, nitrate, $\mathrm{OC}$, and sulfate.

\subsection{Primary $\mathbf{P M}_{2.5}$}

Natural sources of primary $\mathrm{PM}_{2.5}$ include wildfires, sea salt, and windblown dust. Treatment of wildfires and sea salt were discussed previously. Windblown dust has been poorly represented, when not ignored completely, within regional air quality models such as CMAQ (Pierce et al., 2003; Choi and Fernando, 2008). An accurate treatment of windblown dust must incorporate complex atmospheric processes with varying land surfaces and soil data (Pierce et al., 2003). We acquired WRAP RPO 2002 CMAQ-ready natural source windblown dust emissions data. These were created for the WRAP RPO by ENVIRON International Corporation using its own Windblown Dust Model (Mansell et al., 2006). The model considers the necessary parameters for adequate windblown dust emissions estimation as described in Pierce et al. (2003) and Choi and Fernando (2008). The principal model drivers of emissions are wind speed (wind friction velocity) and soil characteristics with varying land cover type (Mansell et al., 2006). The model produces coarse and fine primary particulate emissions.
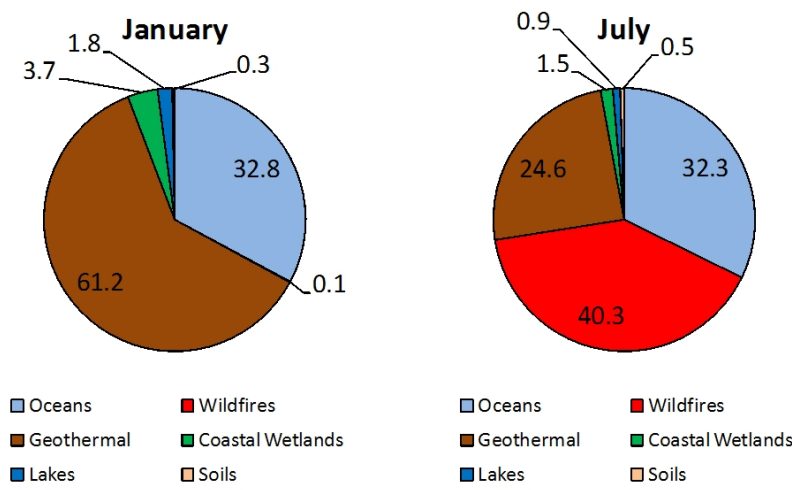

Fig. 2. Percent distribution of natural gaseous sulfur $\left(\mathrm{SO}_{2}+\mathrm{DMS}+\right.$ $\mathrm{H}_{2} \mathrm{~S}$ ) emissions by source.

Table 1. Monthly emissions totals for naturally occurring sulfur gases within the atmospheric modeling domain.

\begin{tabular}{lcc}
\hline Species & $\begin{array}{c}\text { Jan } \\
\mathrm{Mg}\end{array}$ & $\begin{array}{c}\text { Jul } \\
\mathrm{Mg}\end{array}$ \\
\hline $\mathrm{SO}_{2}$ & $5.2 \times 10^{3}$ & $1.2 \times 10^{5}$ \\
$\mathrm{DMS}$ & $3.5 \times 10^{4}$ & $8.8 \times 10^{4}$ \\
$\mathrm{H}_{2} \mathrm{~S}$ & $2.2 \times 10^{4}$ & $2.1 \times 10^{4}$ \\
Total sulfur & $3.0 \times 10^{4}$ & $7.3 \times 10^{4}$ \\
\hline
\end{tabular}

\section{Natural emissions for 2002}

\subsection{Gaseous sulfur}

Distributions of naturally-emitted gaseous sulfur species by source type are shown in Fig. 2 for January and July 2002. Geogenic and ocean sources dominate in January. Wildfires play a much greater role in July. Contributions from inland surface waters, soils and coastal wetlands comprise only about 6\% of the total emissions in January and 3\% in July.

Domain-wide emission totals for the three natural gaseous sulfur species are summarized in Table 1 for January and July of 2002. January natural emissions of gaseous sulfur compounds are dominated by DMS and $\mathrm{H}_{2} \mathrm{~S}$ with $\mathrm{SO}_{2}$ emissions being nearly a factor of 10 smaller. This reverses in July with $\mathrm{SO}_{2}$ emissions being almost $40 \%$ greater than DMS. Figure 3 illustrates the spatial distribution of total sulfur emissions for January and July. The primary difference is due to the abundance of wildfires that occur in summer. Total natural gaseous sulfur emissions in July $\left(7.3 \times 10^{4} \mathrm{Mg}\right)$ are about 2.5 times higher than in January. These results suggest that winter sulfur aerosol formation might be controlled by the slow oxidation of reduced sulfur compounds into $\mathrm{SO}_{2}$ and eventually sulfate. It also implies that natural sulfate aerosol levels should be greater near the US coastlines in winter because the predominant precursors are emitted over the oceans. Wildfires should shift the higher natural sulfate levels inland in summer because of the increase in both $\mathrm{SO}_{2}$ and sulfate aerosol emissions from fires. 


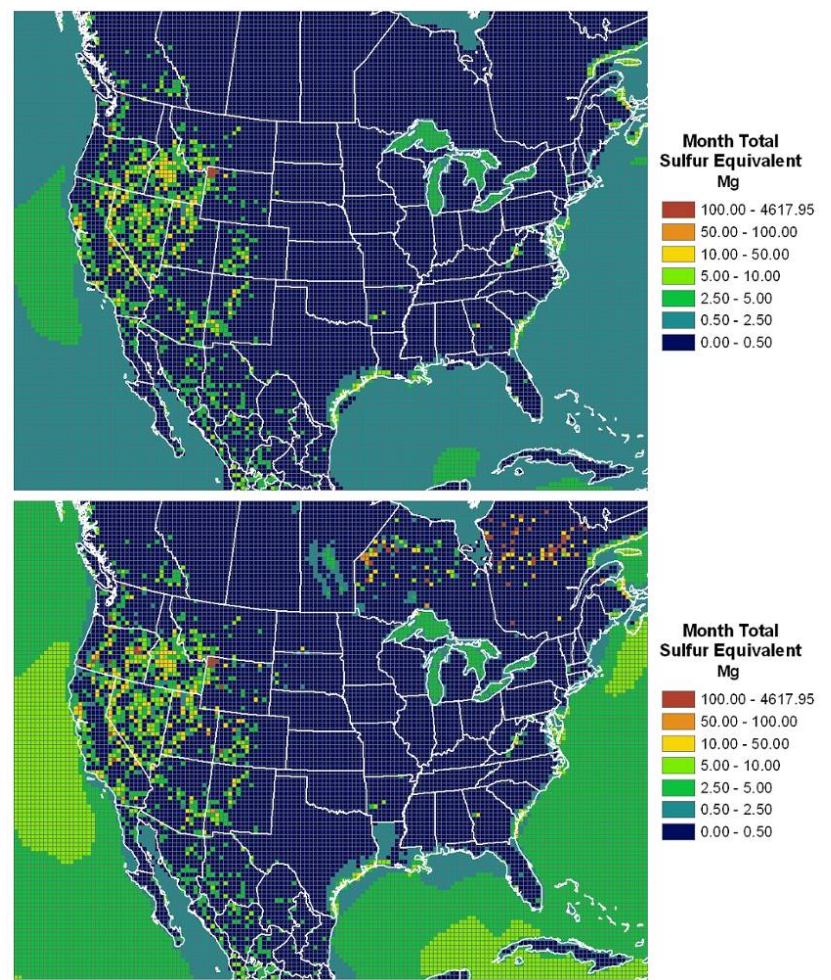

Fig. 3. Total natural gaseous sulfur $\left(\mathrm{SO}_{2}+\mathrm{DMS}+\mathrm{H}_{2} \mathrm{~S}\right)$ emissions, expressed as $\mathrm{Mg}$ of $\mathrm{S}$, calculated for January (top) and July (bottom) 2002 for the atmospheric modeling domain.

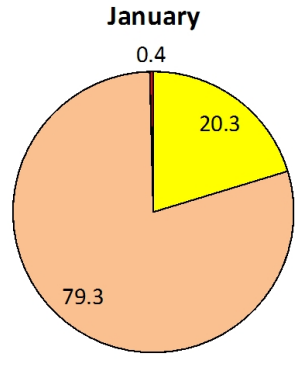

$\square$ Lightning $\square$ Soils $\square$ Wildfires

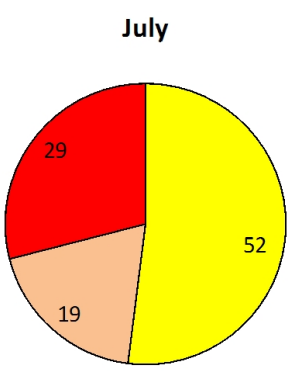

口Lightning 口Soils $\square$ Wildfires
Fig. 4. Percent distribution of natural $\mathrm{NO}_{\mathrm{x}}$ emissions by source.

\section{2 $\quad \mathrm{NO}_{\mathrm{x}}$}

The relative amounts of natural $\mathrm{NO}_{\mathrm{x}}$ emissions are illustrated in Fig. 4. Most January $\mathrm{NO}_{\mathrm{x}}$ comes from soils but lightning accounts for more than half of all emissions in July. Wildfire emissions are nearly nonexistent in January but comprise almost $30 \%$ of total $\mathrm{NO}_{\mathrm{x}}$ in July. Figure 5 shows the January and July spatial distributions of natural $\mathrm{NO}_{\mathrm{x}}$ emissions. Lightning $\mathrm{NO}_{\mathrm{x}}$ is mostly confined to the south-central US and Gulf of Mexico in the middle of winter. By midsummer there are few locations that do not experience some lightning and $\mathrm{NO}_{\mathrm{x}}$ emissions are especially dense over the southeast-
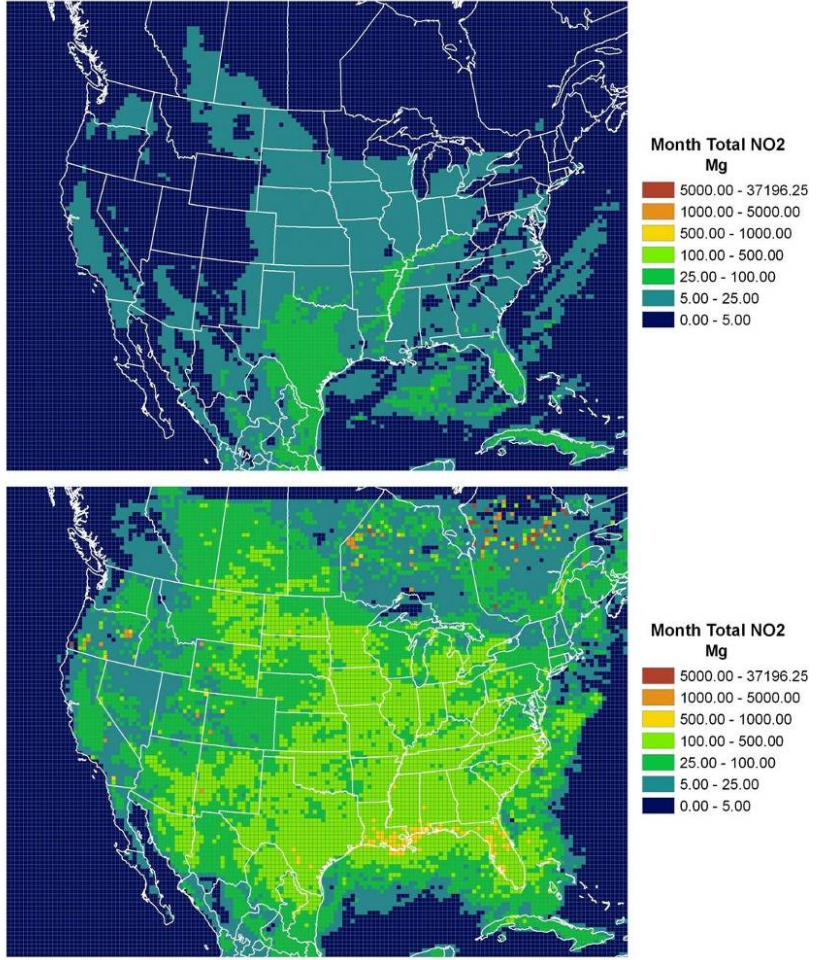

Fig. 5. Total natural $\mathrm{NO}_{\mathrm{x}}$ emissions, expressed as $\mathrm{Mg}$ of $\mathrm{NO}_{2}$, calculated for January (top) and July (bottom) 2002 for the atmospheric modeling domain.

ern US. Wildfires considered naturally-caused that were inventoried for this 2002 simulation occurred primarily across the western US, in Florida and eastern Canada.

Table 2 quantifies the seasonal breakdown of natural $\mathrm{NO}_{\mathrm{x}}$ emissions along with that of other gaseous nitrogen species. Nitrogen in the form of $\mathrm{NO}_{\mathrm{x}}$ is far greater than that emitted as ammonia or nitryl chloride (the latter is confined to marine coastal areas). The data suggest that lightning could occasionally make significant contributions to ozone formation in summer over the southern US, consistent with that reported by Kaynak et al. (2008). Lightning $\mathrm{NO}_{\mathrm{x}}$ also has the greatest potential to contribute to nitrogen deposition in summer over the southern and eastern US.

\section{$\begin{array}{lll}4.3 & \mathrm{NH}_{3}\end{array}$}

Natural ammonia plays a small role in neutralizing acid aerosols and contributing to ammonium nitrate aerosol formation. Monthly emission totals listed in Table 2 indicate the July emissions are much greater than those of January. The higher summer emissions (July: $1.2 \times 10^{5} \mathrm{Mg}=7 \times 10^{9}$ moles) are such that the total moles emitted of natural $\mathrm{NH}_{3}$ exceeds those of natural sulfur species by a factor of 3 . The potential exists for natural $\mathrm{NH}_{3}$ to neutralize natural oxidized sulfur in some locations, especially over the oceans. Also, maritime ammonia emitted in the vicinity of lightning $\mathrm{NO}_{\mathrm{x}}$, 
Table 2. Monthly emissions totals for naturally occurring nitrogen gases within the atmospheric modeling domain.

\begin{tabular}{lcc}
\hline Species & $\begin{array}{c}\text { Jan } \\
\mathrm{Mg}\end{array}$ & $\begin{array}{c}\text { Jul } \\
\mathrm{Mg}\end{array}$ \\
\hline $\mathrm{NO}_{\mathrm{x}}^{\mathrm{a}}$ & $9.2 \times 10^{4}$ & $1.4 \times 10^{6}$ \\
$\mathrm{NH}_{3}$ & $2.6 \times 10^{4}$ & $1.2 \times 10^{5}$ \\
$\mathrm{ClNO}_{2}$ & $8.6 \times 10^{2}$ & $2.2 \times 10^{1}$ \\
Total nitrogen & $5.0 \times 10^{4}$ & $5.2 \times 10^{5}$ \\
\hline
\end{tabular}

${ }^{a}$ Expressed as $\mathrm{NO}_{2}$.

and wildfire ammonia and $\mathrm{NO}_{\mathrm{x}}$ co-emissions, have the potential to form ammonium nitrate aerosols in select locations.

\subsection{Gaseous chlorine}

Natural chlorine emissions are such that airborne gaseous chlorine compounds are confined to air over the oceans and in coastal zones (Fig. 6). Table 3 indicates that hydrochloric acid is the predominant gas species with nitryl chloride a distant second. Both originate from sea salt which is more abundant when winds are strong. This means that winter and spring are generally the periods when sea salt and associated chlorine gas species will have the largest contribution to air quality and atmospheric chemistry. Also, $\mathrm{ClNO}_{2}$ levels will be much higher when natural and anthropogenic emissions are combined because this analysis tied $\mathrm{ClNO}_{2}$ to nearby $\mathrm{NO}_{\mathrm{x}}$ levels. When total gas+aerosol chlorine is considered sea salt is dominant accounting for $99 \%$ of all airborne chlorine.

\subsection{VOCs and CO}

Volatile organic compounds are dominated by biogenic sources but significant contributions are also made by wildfires. The US Southeast shows the highest VOC emissions throughout the year (Fig. 7) but wildfires increase western US emissions in summer. July VOC emissions for 2002 are more than 10 times greater than those for January (Table 4). The contribution of wildfires causes July CO emissions to be higher than those in January by more than a factor of 100 . Thus, natural VOC and CO emissions are nearly equal in January but $\mathrm{CO}$ emissions are about 3 times greater than VOCs in July.

\subsection{Particulate matter}

Natural particle emissions are divided into two categories: coarse and fine. Coarse mass $\left(\mathrm{PM}_{c}\right)$ is not speciated and is not chemically reactive in the CMAQ model (there is an exception to this - see below). However, fine mass $\left(\mathrm{PM}_{2.5}\right)$ is divided into chemical components and these are described separately.

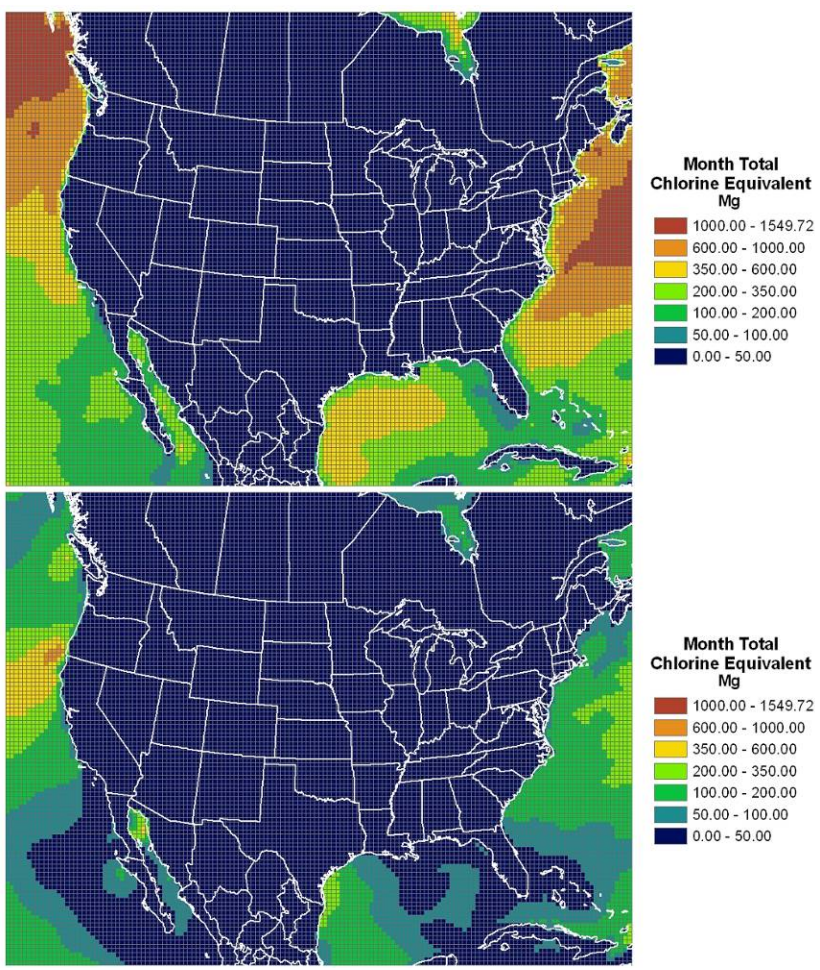

Fig. 6. Total natural chlorine $\left(\mathrm{HCl}+\mathrm{ClNO}_{2}+\right.$ sea salt $\left.\mathrm{Cl}\right)$ emissions, expressed as $\mathrm{Mg}$ of $\mathrm{Cl}$, calculated for January (top) and July (bottom) 2002 for the atmospheric modeling domain.

Table 3. Monthly emissions totals for naturally occurring chlorine gases within the atmospheric modeling domain.

\begin{tabular}{lcc}
\hline Species & Jan & Jul \\
& $\mathrm{Mg}$ & $\mathrm{Mg}$ \\
\hline $\mathrm{HCl}$ & $1.7 \times 10^{4}$ & $5.7 \times 10^{3}$ \\
$\mathrm{ClNO}_{2}$ & $8.6 \times 10^{2}$ & $2.2 \times 10^{1}$ \\
Total chlorine & $1.7 \times 10^{4}$ & $5.6 \times 10^{3}$ \\
\hline
\end{tabular}

Natural coarse mass originates primarily from windblown dust (anthropogenically-derived road dust is not considered "natural" in the current modeling) and wildfires. Thus, $\mathrm{PM}_{c}$ emissions are greater when and where winds are stronger and when/where fires occur. However, soil dryness and vegetation cover also play a role. Figure 8 illustrates the January and July spatial distribution of natural $\mathrm{PM}_{c}$ emissions. July $\mathrm{PM}_{c}$ emissions are roughly twice as high as those in January (Table 5). These $\mathrm{PM}_{c}$ values do not include coarse sea salt which is tracked separately in CMAQ. Coarse sea salt mass is confined to grid cells over the oceans and along the coasts. Total sea salt emissions (coarse and fine mass), listed separately in Table 5, are over four times greater in January than July because of stronger winter winds. 


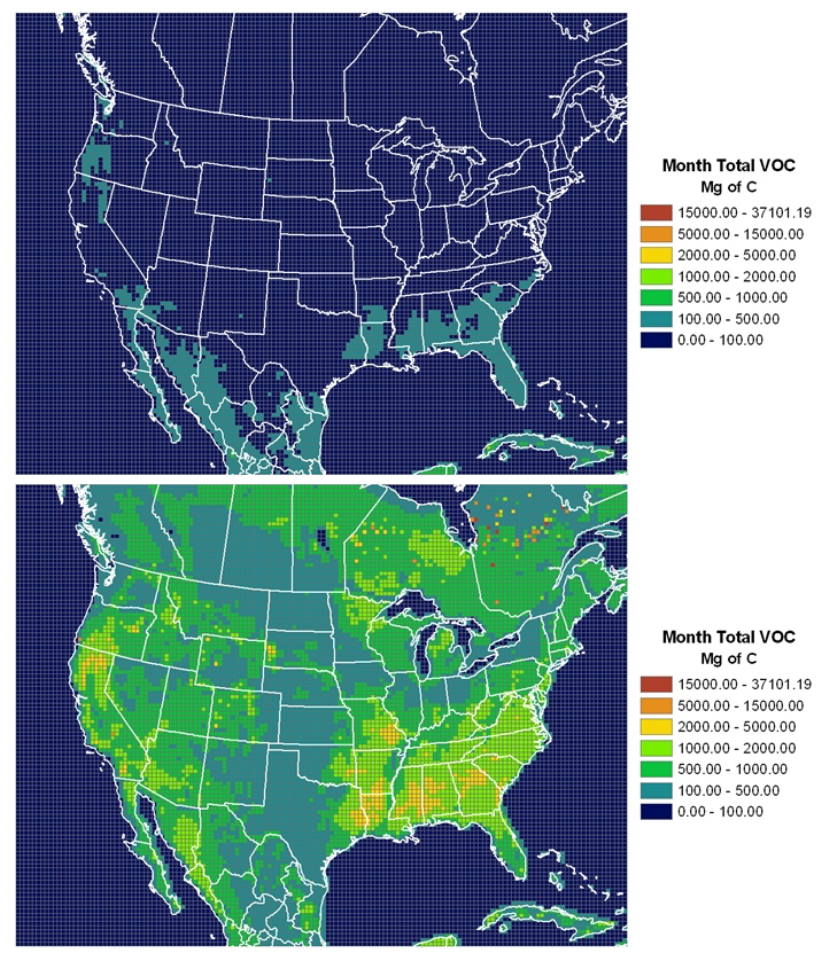

Fig. 7. Total natural VOC emissions (Mg of C) calculated for January (top) and July (bottom) 2002 for the atmospheric modeling domain.

Table 4. Monthly emissions totals for naturally occurring nonmethane volatile organic compounds (VOCs) and $\mathrm{CO}$ within the atmospheric modeling domain.

\begin{tabular}{lcc}
\hline Species & $\begin{array}{c}\mathrm{Jan} \\
\mathrm{Mg}\end{array}$ & $\begin{array}{c}\mathrm{Jul} \\
\mathrm{Mg}\end{array}$ \\
\hline VOCs $^{\mathrm{a}}$ & $5.3 \times 10^{5}$ & $7.7 \times 10^{6}$ \\
$\mathrm{CO}$ & $1.9 \times 10^{5}$ & $2.1 \times 10^{7}$ \\
Total reactive carbon & $6.1 \times 10^{5}$ & $1.7 \times 10^{7}$ \\
\hline
\end{tabular}

${ }^{a}$ Expressed as equivalent carbon.

Fine particle mass emissions from natural sources are divided into sulfate, nitrate, organic and elemental carbonaceous, nonreactive and sea salt aerosols. Sulfate, nitrate, OC, and EC are emitted by wildfires. The nonreactive component of $\mathrm{PM}_{2.5}$ is emitted by wildfires and windblown dust. Total $\mathrm{PM}_{2.5}$ mass emissions (which include the minor fine sea salt component) are plotted in Fig. 9 for January and July. In January $\mathrm{PM}_{2.5}$ is predominantly composed of nonreactive dust while OC is the major component in July (Table 5).

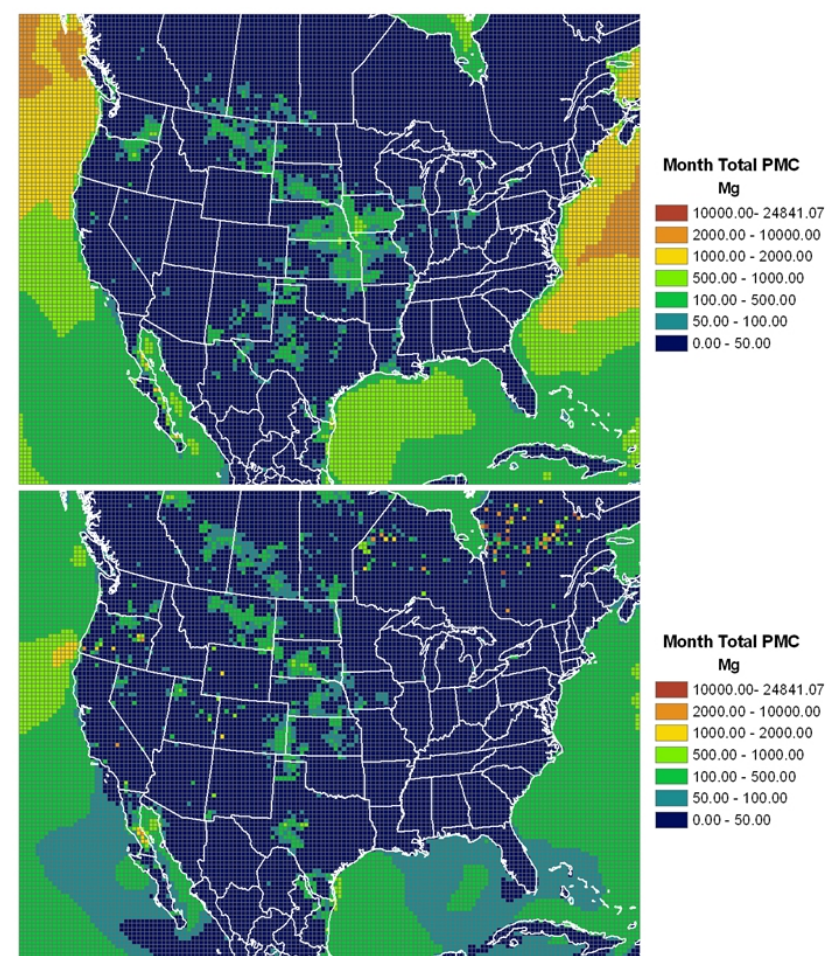

Fig. 8. Total natural $\mathrm{PM}_{c}$ emissions $(\mathrm{Mg})$ calculated for January (top) and July (bottom) 2002 for the atmospheric modeling domain.

Table 5. Monthly emissions totals for naturally occurring particulate matter within the atmospheric modeling domain.

\begin{tabular}{lcc}
\hline Species & $\begin{array}{c}\text { Jan } \\
\mathrm{Mg}\end{array}$ & $\begin{array}{c}\text { Jul } \\
\mathrm{Mg}\end{array}$ \\
\hline $\mathrm{PM}_{c}^{\mathrm{a}}$ & $2.2 \times 10^{5}$ & $4.6 \times 10^{5}$ \\
$\mathrm{PM}_{2.5}^{\mathrm{a}}$ & $2.5 \times 10^{4}$ & $1.7 \times 10^{6}$ \\
Sulfate $^{\mathrm{b}}$ & $2.7 \times 10^{1}$ & $3.3 \times 10^{4}$ \\
Nitrate $^{\mathrm{b}}$ & $2.7 \times 10^{0}$ & $3.3 \times 10^{3}$ \\
OC $^{\mathrm{b}}$ & $1.0 \times 10^{3}$ & $1.3 \times 10^{6}$ \\
EC $^{\mathrm{b}}$ & $2.2 \times 10^{2}$ & $2.7 \times 10^{5}$ \\
Nonreactive $^{\mathrm{b}}$ & $2.4 \times 10^{4}$ & $1.0 \times 10^{5}$ \\
Sea salt $^{\mathrm{c}}$ & $4.5 \times 10^{6}$ & $1.1 \times 10^{6}$ \\
\hline
\end{tabular}

a Does not include sea salt component.

b Fine mass only.

${ }^{\mathrm{c}}$ Includes both fine and coarse mass.

\section{Comparisons of anthropogenic and natural emissions}

Anthropogenic emissions that are compared here to natural emissions were compiled for the VISTAS regional haze modeling exercise (MACTEC, 2008). The VISTAS Base G2 emissions inventory is considered one of the best available for this period. Its spatial domain and $36-\mathrm{km}$ grid structure is identical to that used in the current natural emissions 


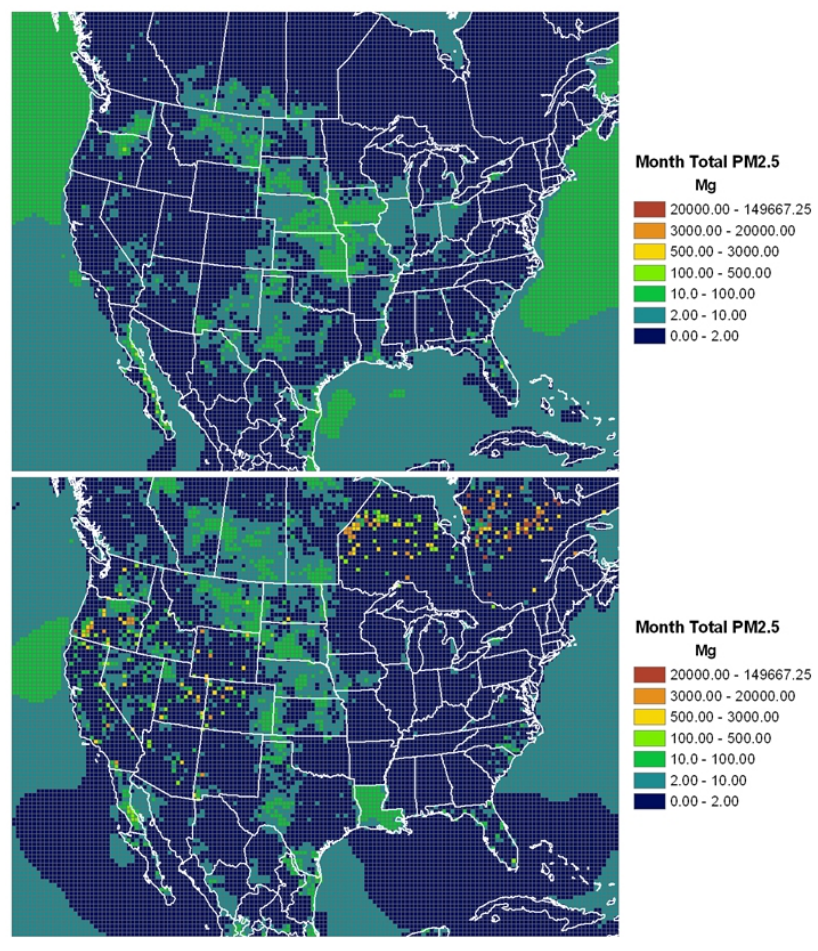

Fig. 9. Total natural $\mathrm{PM}_{2.5}$ (sum of sulfate, nitrate, OC, EC, nonreactive and fine sea salt) emissions ( $\mathrm{Mg}$ ) calculated for January (top) and July (bottom) 2002 for the atmospheric modeling domain.

analysis. The Base G2 anthropogenic inventory represents "typical" 2000-2004 point source and US wildfire emissions in order to avoid the irregularities associated with both of these source classes. This assumption also affects the natural emissions data developed in this study because the wildfires emissions were based on the techniques and data supplied by VISTAS. However, wildfire emissions in Canada and Mexico have a more mixed pedigree and were not strictly representative of 2002 but the overall impact on results should be minor. Other than wildfires, the natural emissions described here are specific to the year 2002.

Figure 10 compares July VISTAS 2002 anthropogenic emissions with those in the enhanced July 2002 natural emissions data base developed for this effort. Total gaseous $\left(\mathrm{SO}_{2}+\mathrm{DMS}+\mathrm{H}_{2} \mathrm{~S}\right)$ sulfur is dominated by anthropogenic emissions in 2002. The fraction attributable to man-made sources continues to decline with $\mathrm{SO}_{2}$ emission controls on coal-fired electric power plants and low-sulfur diesel fuel for on-road use. However, anthropogenic sources will continue to dominate this emissions category over the next $10+$ years.

Anthropogenic sources also make up the majority of $\mathrm{NO}_{\mathrm{x}}$ emissions but only by about $12 \%$. The natural emission fraction is reduced from $44 \%$ to about $21 \%$ if lightning $\mathrm{NO}_{\mathrm{x}}$ is omitted from the data set. This omission is probably the most indefensible of the routine assumptions made when building emissions data sets for regulatory photochemical modeling.
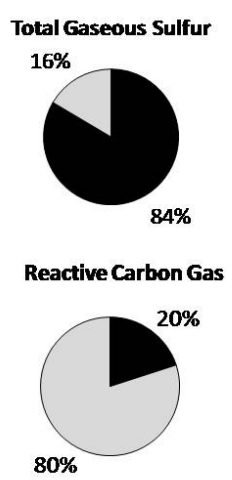
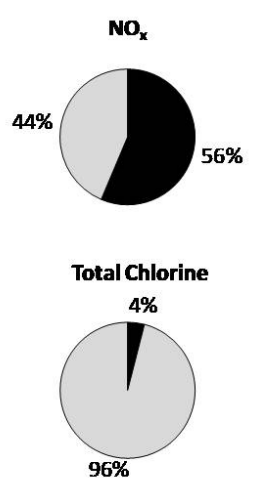
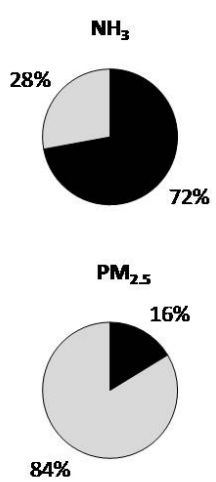

Fig. 10. Relative proportions of anthropogenic (solid black) and natural (gray) emissions within the modeling domain for the modified VISTAS July 2002 emissions inventory developed for this study. "Total Gaseous Sulfur" represents the sum of sulfur in $\mathrm{SO}_{2}+\mathrm{DMS}+\mathrm{H}_{2} \mathrm{~S}$. "Reactive Carbon Gas" represents the sum of carbon in non-methane VOCs+CO. "Total Chlorine" represents the sum of chlorine in $\mathrm{HCl}+\mathrm{ClNO}_{2}+$ sea salt. The $\mathrm{PM}_{2.5}$ comparison includes sea salt in the fine particle fraction.

A future paper describes the impact of lightning $\mathrm{NO}_{\mathrm{x}}$ on simulated air quality, including ground-level ozone.

Ammonia emissions are dominated by anthropogenic activities, especially livestock farming. The addition of ocean $\mathrm{NH}_{3}$ emissions did little to alter the balance between natural and man-made $\mathrm{NH}_{3}$ sources in this modeling domain.

No changes were made to emissions of VOCs or $\mathrm{CO}$. The large dominance of natural sources emitting reactive carbonaceous gases is the same that has existed since photochemical modeling began over two decades ago. The dominance of natural emissions is not as large in winter due to the large decline in biogenic VOC emissions and wildfires.

Finally, about $99 \%$ of natural primary fine particle emissions are associated with windblown dust and wildfires. The recent addition of fine sea salt emissions did little to change this balance because sea salt is so geographically limited and most of its mass is in the coarse size fraction.

\section{Conclusions}

A wider range of natural pollutant emissions have been included in an expanded emissions data base for use in the US EPA CMAQ air regulatory model. Lightning $\mathrm{NO}_{\mathrm{x}}$, DMS and $\mathrm{H}_{2} \mathrm{~S}$ from oceans and continental sources, and chlorine $(\mathrm{HCl}$ and $\mathrm{ClNO}_{2}$ ) from reactions involving sea salt are all new additions to the species already present in a data base developed for modeling regional levels of fine particles. Lightning $\mathrm{NO}_{\mathrm{x}}$ in July was estimated to total $4.8 \times 10^{5} \mathrm{Mg}$ equal to $52 \%$ of the total $\mathrm{NO}_{\mathrm{x}}$ from all natural sources, $40 \%$ of all anthropogenic $\mathrm{NO}_{\mathrm{x}}$ emissions, and $23 \%$ of the July sum of natural and anthropogenic $\mathrm{NO}_{\mathrm{x}}$ emissions. This amounts to a large increase in total domain-wide $\mathrm{NO}_{\mathrm{x}}$ emissions, consistent 
with the findings of Kaynak et al. (2008). However, the characteristics of $\mathrm{LNO}_{\mathrm{x}}$ are such that on average $90 \%$ of $\mathrm{LNO}_{\mathrm{x}}$ is emitted above a height of $2500 \mathrm{~m}$ (i.e., well above the afternoon convective boundary layer). This means that $\mathrm{LNO}_{\mathrm{x}}$ is unlikely to strongly influence ozone photochemistry in the vicinity of where it is generated and may be more important for its influence on background levels of $\mathrm{NO}_{\mathrm{x}}$ and ozone in the free troposphere. Quantifying the implications for regional ozone and nitrogen deposition requires detailed model simulations.

Sources other than wildfires contribute significantly to the total of natural sulfur emissions. Even so, anthropogenic $\mathrm{SO}_{2}$ emissions are still dominant but declining steadily. In winter, when fewer wildfires occur, geogenic and marine sources of sulfur account for nearly all natural sulfur emissions. In July, the sources added to the existing inventory account for $60 \%$ of all natural gaseous sulfur emissions. Taking advantage of the newly added emissions of DMS and $\mathrm{H}_{2} \mathrm{~S}$ require modifications to the gas and aqueous chemical modules in models like CMAQ. Impacts of these natural emissions on aerosol modeling are expected to be very small in polluted areas but should contribute to background particle levels in clean environments. Modeling the contributions of DMS and $\mathrm{H}_{2} \mathrm{~S}$ to air quality makes possible the use of models like CMAQ for characterizing natural aerosol background levels.

Recent experimental evidence and model results have demonstrated the importance of chlorine emissions on local photochemistry in polluted coastal environments (Knipping and Dabdub, 2003; Tanaka et al., 2003b; Chang and Allen, 2006). The addition of natural $\mathrm{HCl}$ and $\mathrm{ClNO}_{2}$ emissions to an existing inventory increase total natural chlorine emissions by only a tiny amount $(\sim 1 \%)$. This is due to the predominance of sea salt chloride as the primary source of atmospheric chlorine. There is a need to update existing aerosol modules in models like CMAQ to more accurately simulate the dechlorination of sea salt particles and the subsequent release of reactive chlorine to the atmosphere. Changes are also required in CMAQ so that its chemistry modules can simulate oxidation reactions involving reactive chlorine. Many of the processes involved in emission production from natural sources, such as seasonal variance, still require further research. It is recommended that further investigation be performed on temporal allocation of the natural sources for which we applied default profiles. Furthermore, one caveat should be noted; there was a misinterpretation regarding diel release of oceanic $\mathrm{ClNO}_{2}$ we present in Fig. A7 as referenced from Osthoff et al. (2008). Our interpreted temporal allocation fails to include nighttime levels provided in Osthoff et al. (2008) and most recently by Thornton et al. (2010). Fortunately our interpretation captures the early morning peak flux given by both Osthoff et al. (2008) and Thornton et al. (2010) and conserves diel totals. Only the diel variation is misconstrued; nonetheless, the emissions of $\mathrm{ClNO}_{2}$ should receive further nighttime allocations in any future work as defined by studies such as Osthoff et al. (2008) and Thornton

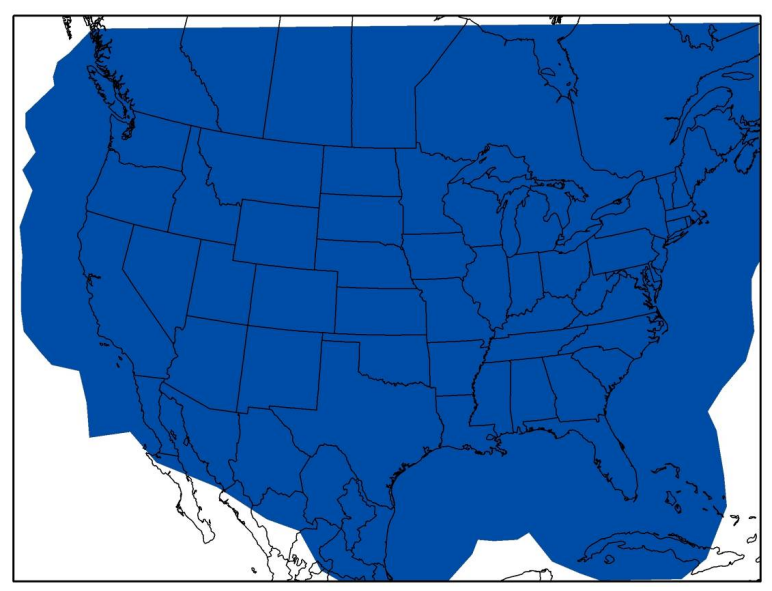

Fig. A1. The geographic extent of NLDN flash data included in this modeling is shown relative to the $36-\mathrm{km}$ modeling domain.

et al. (2010). However, for our subsequent CMAQ modeling this oversight is very insignificant given that this GEIA inventory source of $\mathrm{ClNO}_{2}$ represents less than $1 \%$ of the total chlorine source we simulated for our modeling inventory. Estimated uncertainties in emissions for natural sources range from about $50 \%$ to around a factor of 10 according to the sources we have referenced.

\section{Appendix A}

\section{Supplemental information on the simulation of natural source emissions}

\section{A1 $\mathrm{NO}_{\mathrm{x}}$}

Natural sources of $\mathrm{NO}_{\mathrm{x}}$ simulated in this work include soils, wildfires, and lightning. Soil NO emissions were directly estimated using established methods within SMOKE via the BEIS (Biogenic Emissions Inventory System) model version 3.14. Emissions of $\mathrm{NO}_{\mathrm{x}}$ from wildfires also used established methods by adopting the wildfire records in existing Regional Planning Organization (RPO) inventories for further processing within SMOKE. Lightning NO emissions from detected lightning flashes were based on lightning flash data as reported in 2002 by the National Lightning Detection Network (NLDN). The CMAQ modeling domain used in this work is the rectangular area covered by the map in Fig. A1. The spatial extent of the NLDN data set applied for this domain is shown in blue. Rather than applying a single NO production factor for flash emissions rates (as has been done elsewhere), the emissions rates for flashes in the 2002 simulation used an algorithm to estimate flash-specific emissions rates. This approach, referred to as the mean peak current method, is a variation on the methods described by Price et al. (1997), DeCaria et al. (2000), and Ott et al. (2010). The 
basis of this approach is the cloud-to-ground (CG) flash data from the NLDN data set. We introduce separate treatment of positive flash return strokes and use all NLDN peak current values (rather than setting a minimum threshold) as recorded in the data set.

The average current (amperes) for both a negative $\left(C_{\mathrm{n}}\right)$ and a positive $\left(C_{\mathrm{p}}\right) \mathrm{CG}$ flash was calculated as

$C_{\mathrm{n}}, C_{\mathrm{p}}=F_{t} \cdot\left[S_{1}+\left(F_{\mathrm{s}} \cdot S_{s}\right)\right] \cdot I_{\mathrm{pc}}$

where $F_{t}$ is the total number of flashes, $S_{1}$ and $S_{s}$ are constants $\left(3.12 \times 10^{-4}\right.$ and $1.39 \times 10^{-4}$, respectively, based on Price et al., 1997), $F_{\mathrm{S}}$ is the total number of return strokes of the flash minus the first return stroke, and $I_{\mathrm{pc}}$ is the peak current (A) for the flash.

The energy released in negative $\left(E_{\mathrm{n}}\right)$ and positive $\left(E_{\mathrm{p}}\right) \mathrm{CG}$ flashes is calculated as

$E_{\mathrm{n}}=C_{\mathrm{n}} \cdot V_{\mathrm{n}}$

and

$E_{\mathrm{p}}=C_{\mathrm{p}} \cdot V_{\mathrm{p}}$

where $V_{\mathrm{n}}$ and $V_{\mathrm{p}}$ are the breakdown potentials in air for negative and positive flashes, respectively $\left(-3 \times 10^{8} \mathrm{~V}\right.$ and $5 \times 10^{8} \mathrm{~V}$ based on Price et al., 1997). The total energy $E_{\mathrm{cg}}$ (in joules) per CG flash is then computed as

$E_{\mathrm{cg}}=E_{\mathrm{n}}+E_{\mathrm{p}}$

Thus, the CG flash total NO was calculated as

$T_{\mathrm{cg}}=E_{\mathrm{cg}}\left(P / N_{\mathrm{a}}\right)$

where $P$ is the production rate of NO from a CG flash (a constant value of $1 \times 10^{16}$ molecules per joule based on Price et al., 1997) and $N_{a}$ is Avogadro's number needed to express $T_{\text {cg }}$ in units of moles of NO.

Data on IC flashes are not included in NLDN data sets. Previous research on IC flashes suggested setting the IC/CG NO production ratio to 1/10. More recently, Ott et al. (2007, 2010) suggested a much stronger contribution from IC to NO production. After an extensive review of current literature and recent research we decided to set the IC NO production per flash equal to the CG NO production per flash primarily based on the research of Ott et al. $(2007,2010)$. An ICto-CG flash ratio of 2.7 was assumed taken based on Pierce et al. (1999) which stems from the work of Price and Rind (1993). This falls in the range of climatological IC to CG ratios over the continental US (2.64-2.94) reported by Boccippio et al. (2001). It follows from this that IC NO production is computed as

$T_{\mathrm{ic}}=2.7 T_{\mathrm{cg}}$

The vertical atmospheric distribution of lightning $\mathrm{NO}_{\mathrm{x}}$ has been studied by a number of researchers including Novak and Pierce (1993), Pickering et al. (1998), Wang et al. (1998),

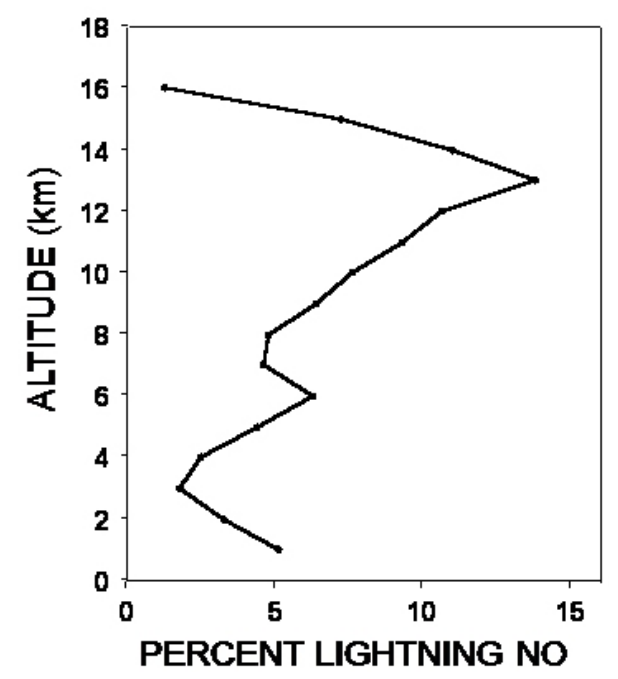

Fig. A2. Vertical allocation of lightning NO emissions based on modified Pickering et al. (1998) mid-latitude continental profile. Modifications were made as suggested by L. Ott (personal communication, 2007) to eliminate the large peak in the lowest kilometer in the Pickering et al. (1998) profile.

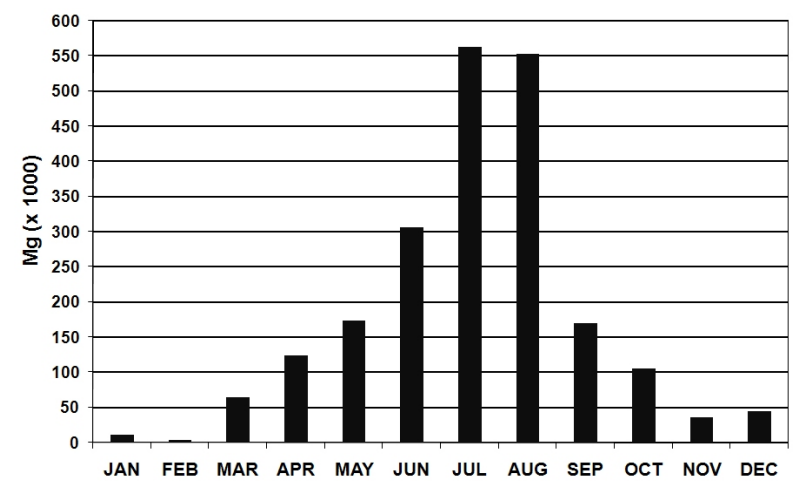

Fig. A3. Monthly domain-wide lightning NO total emissions for the 2002 natural emissions

DeCaria et al. (2000), Hudman et al. (2007), and Ott et al. (2007, 2010). Most of the published work uses some variation of the Pickering et al. (1998) vertical distribution. Thus, estimated lightning NO emissions in this analysis were distributed vertically through the troposphere using the midlatitude continental profile from Pickering et al. (1998) modified as suggested by Lesley Ott (personal communication, 2007) to eliminate the large peak in the lowest kilometer. This profile, illustrated in Fig. A2, allocates about 5\% of the $\mathrm{NO}$ to the lowest $1000 \mathrm{~m}$ of the atmosphere and redistributes the remaining mass to higher layers. Figure A3 illustrates the monthly distribution of estimated lightning NO emissions showing the expected strong summer peak. 
Table A1. Natural source reduced sulfur emissions factors.

\begin{tabular}{lcc}
\hline Source & $\begin{array}{c}\mathrm{H}_{2} \mathrm{~S} \\
\mu \mathrm{g} \mathrm{m}^{-2} \text { day }^{-1}\end{array}$ & $\begin{array}{c}\text { DMS } \\
\mu \mathrm{g} \mathrm{m}^{-2} \text { day }^{-1}\end{array}$ \\
\hline Ocean $^{\mathrm{a}}$ & 4 & $27-591^{\mathrm{b}}$ \\
Freshwater Lakes $^{\mathrm{c}}$ & 64.8 & 38.4 \\
Great Salt Lake $^{\mathrm{d}}$ & 64.8 & 43.4 \\
Coastal Wetlands $^{\mathrm{e}}$ & 816 & 2664 \\
\hline
\end{tabular}

${ }^{\mathrm{a}} \mathrm{H}_{2} \mathrm{~S}$ factor is derived from Andreae and Jaeschke (1992).

b Approximate factor range for ocean DMS based on reallocation of annual sulfur values from Kloster et al. (2006) to daily values.

c Taken from values from the lower range of freshwater sulfur flux estimates derived from several studies including Richards et al. (1991), Bates et al. (1992), Giblin and Wieder (1992), Gröne (1997), Bodenbender et al. (1999), and Sharma et al. (1999).

d Given the lack of available information on natural emissions from the Great Salt Lake the $\mathrm{H}_{2} \mathrm{~S}$ factor applied for freshwater lakes was conservatively applied. The DMS factor is derived from Richards et al. (1994).

e Based on average of factors produced from a number of studies on sulfur flux from salt marsh and Spartina Alterniflora including Steudler et al. (1985), Giblin and Wieder (1992), and DeLaune et al. (2002).

Table A2. Sulfur emissions factors for geothermal sources.

\begin{tabular}{lc}
\hline $\begin{array}{l}\text { Source } \\
\text { (number of discrete emission points) }\end{array}$ & $\begin{array}{c}\text { Sulfur Equivalent } \\
\text { T/day }\end{array}$ \\
\hline Mt. St. Helens (1) $^{\mathrm{a}}$ & 94 \\
Mt. Hood (1) $^{\mathrm{b}}$ & 6 \\
Mt. Baker (1) $^{\mathrm{c}}$ & 5.2 \\
Yellowstone geothermal features (138) $^{\mathrm{d}}$ & 2.7 (for each) \\
Non-Yellowstone geothermal features (1703) $^{\mathrm{e}}$ & 0.1 (for each) \\
\hline
\end{tabular}

a Approximated based on low-to-mid-range value extracted from $\mathrm{SO}_{2}$ measurements from Chapter 26, Figure 16 of Sherrod et al. (2008).

b From Chapter 26, Table 1 of Sherrod et al. (2008).

${ }^{c}$ McGee et al. (2001).

d William Evans, USGS, personal communication, 2005.

e Set to $1 \%$ of the $\mathrm{H}_{2} \mathrm{~S}$ estimated for non-eruptive volcanoes by Berresheim and Jaeschke (1983).

\section{A2 Sulfur}

Natural sources of sulfur simulated in this work included $\mathrm{SO}_{2}$ from wildfires, $\mathrm{SO}_{2}$ and $\mathrm{H}_{2} \mathrm{~S}$ from geothermal sources, $\mathrm{H}_{2} \mathrm{~S}$ and DMS from inland lakes, oceans, coastal wetlands, and sea salt sulfate. Treatment of wildfire emissions in this work introduced no new techniques and simply used a top-down method of selecting wildfire records from the existing RPO inventories for further processing with the SMOKE system. Likewise, sulfates from sea salt required no unique treatment

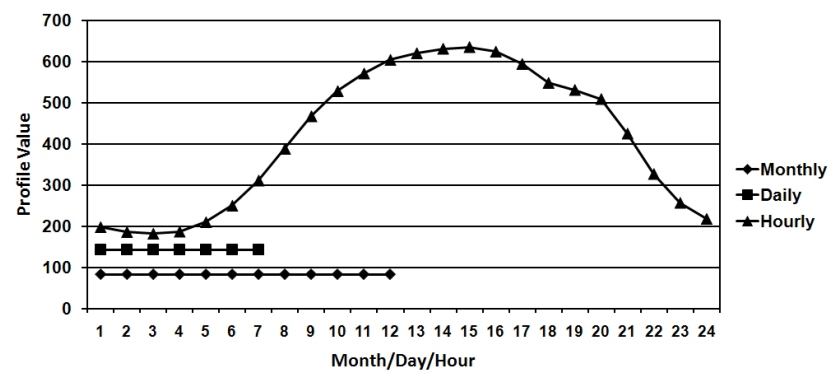

Fig. A4. SMOKE v2.5 default hourly temporal profile for natural sources applied to sulfur emissions from ocean, coastal wetland, freshwater, the Great Salt Lake, and geothermal sources. Default monthly and daily temporal allocation profiles are also shown.

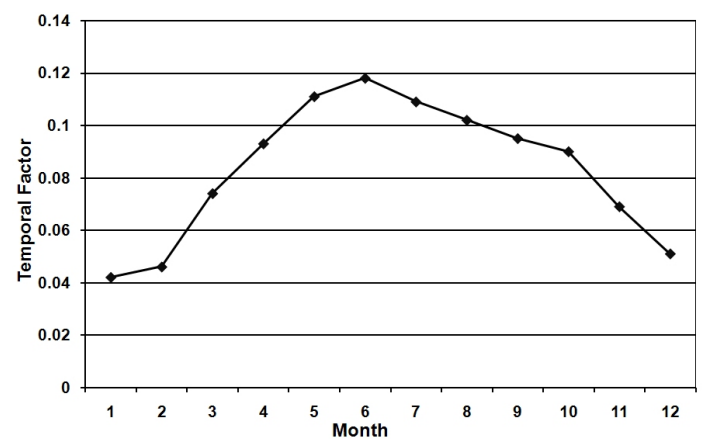

Fig. A5. Ocean DMS monthly temporal profile derived from the work of Kettle and Andreae (2000) applied to the annual mean flux of sulfur from the oceans as delineated by Kloster et al. (2006).

prior to processing in CMAQ because sea salt emissions are simulated from within CMAQ beginning with CMAQ version 4.5. The remaining natural sulfur sources required investigation of literature for acceptable emissions factors. Summaries of the emissions factors applied within this simulation are provided in Tables A1 and A2. Figure A4 illustrates the hourly temporal profile (the default within SMOKE v2.5) for natural sources that was applied in supplement to the emissions factors to produce hourly emissions for a representative day from oceans, coastal wetlands, freshwater lakes, the Great Salt Lake, and geothermal sources. The one instance in which direct allocation to a representative day was not employed involved DMS emissions from oceans. These emissions were first allocated into monthly values based on the work of Kettle and Andreae (2000) as shown in the monthly temporal profile provided in Fig. A5. Incorporating monthly/seasonal variability to the emissions from sulfur sources (other than ocean DMS) should be explored for future work.

Simulating reduced sulfur $\left(\mathrm{H}_{2} \mathrm{~S}\right.$ and DMS $)$ from soils was based on a simple proportionality factor. This factor was based on the ratio of the soil release of $\mathrm{NO}_{\mathrm{x}}$ and reduced sulfur as estimated by NAPAP (1991). NAPAP (1991) provides 
annual estimates of soil release of $\mathrm{NO}_{\mathrm{x}}, \mathrm{H}_{2} \mathrm{~S}$, and DMS for the contiguous United States. A more sophisticated approach is not warranted at this time. Using $\mathrm{NO}_{\mathrm{x}}$ as a spatial surrogate, the conversion factors derived from the NAPAP soil flux estimates were

$$
\begin{aligned}
\mathrm{H}_{2} \mathrm{~S} \text { conversion factor }= & 1,570 \mathrm{Mg} \\
& \text { of } \mathrm{H}_{2} \mathrm{~S} / 1,200,000 \mathrm{Mg} \text { of } \mathrm{NO}_{\mathrm{x}}
\end{aligned}
$$

DMS conversion factor $=1,640 \mathrm{Mg}$

$$
\text { of DMS/1,200, } 000 \mathrm{Mg} \text { of } \mathrm{NO}_{\mathrm{x}}
$$

The resulting conversion factors for $\mathrm{H}_{2} \mathrm{~S}\left(1.31 \times 10^{-3}\right)$ and DMS $\left(1.37 \times 10^{-3}\right)$ were then directly applied to the SMOKE v2.5 Biogenic Emissions Inventory System (BEIS3.14) processor results for soil NO to estimate reduced sulfur emissions.

\section{A3 Chlorine}

Natural sources of chlorine simulated included sea salt aerosols of fine and coarse chloride (estimated from CMAQ as mentioned in the previous section on natural sulfur) and gaseous emissions of $\mathrm{HCl}$ and $\mathrm{ClNO}_{2}$ from the oceans. The special treatment performed in this simulation to produce emissions of $\mathrm{HCl}$ and $\mathrm{ClNO}_{2}$ is described further here. Annual totals of $\mathrm{HCl}$ and $\mathrm{ClNO}_{2}$ from oceans were taken from the GEIA Reactive Chlorine Emissions Inventory (RCEI) (Erickson et al., 1999). This inventory is available online at http://www.geiacenter.org/presentData/ reactivechlorine.html. The GEIA RCEI inventory was then spatially allocated to our modeling domain using GIS (geographic information system) software. The GEIA RCEI provided annual totals for the GEIA $1^{\circ} \times 1^{\circ}$ global domain that were then assigned to the $36 \times 36 \mathrm{~km}$ grid cells in the modeling domain. Once the annual totals per grid cell were calculated they were then allocated into natural and anthropogenic components. The GEIA data set did not provide separate anthropogenic and natural emission estimates. Therefore, factors had to be produced to create these two separate components. This was done by determining the ratio of natural to anthropogenic $\mathrm{NO}_{\mathrm{x}}$ over land near the oceans and then partitioning the GEIA fluxes proportionately into natural and anthropogenic components. $\mathrm{NO}_{\mathrm{x}}$ ratios for natural and anthropogenic component differentiation were created for each month from the emission data base. Essentially, a natural weighting or percentage was created with the remainder assumed to be anthropogenic. The natural and anthropogenic component ratios calculated are provided in Table A3. Before these monthly natural and anthropogenic component split factors could be applied, the annual GEIA RCEI emissions totals per modeling grid cell had to first be allocated to each month of the simulation. Table A4 provides the allocations factors for distributing annual totals to
Table A3. Monthly split-factors (component percentages) derived from ocean/coastline $\mathrm{NO}_{\mathrm{x}}$ ratios that were applied to the GEIA RCEI (Reactive Chlorine Emissions Inventory) to produce natural and anthropogenic components from annual total chlorine (i.e. $\mathrm{HCl}$ and $\mathrm{CINO} 2$ referenced in Table A4).

\begin{tabular}{lcc}
\hline Month & $\begin{array}{c}\text { NATURAL \% } \\
\text { of Total Chlorine }\end{array}$ & $\begin{array}{c}\text { ANTHROPOGENIC \% } \\
\text { of Total Chlorine }\end{array}$ \\
\hline Jan & 13 & 87 \\
Feb & 12 & 88 \\
Mar & 14 & 86 \\
Apr & 16 & 84 \\
May & 14 & 86 \\
Jun & 16 & 84 \\
Jul & 17 & 83 \\
Aug & 17 & 83 \\
Sep & 16 & 84 \\
Oct & 16 & 84 \\
Nov & 16 & 84 \\
Dec & 14 & 86 \\
\hline
\end{tabular}

Table A4. Monthly allocation factors applied to the GEIA RCEI (Reactive Chlorine Emissions Inventory) to produce monthly $\mathrm{HCl}$ and $\mathrm{ClNO}_{2}$ emissions from annual totals. Factors in this table may not sum to one due to rounding.

\begin{tabular}{lcc}
\hline Month & $\mathrm{HCl}$ & $\mathrm{ClNO}_{2}$ \\
\hline Jan & .153198 & .26936 \\
Feb & .157936 & .16835 \\
Mar & .125822 & .06734 \\
Apr & .089628 & .03367 \\
May & .049091 & .010101 \\
Jun & .041326 & .006734 \\
Jul & .038562 & .005051 \\
Aug & .039747 & .005051 \\
Sep & .047380 & .013468 \\
Oct & .055146 & .050505 \\
Nov & .088575 & .13468 \\
Dec & .113582 & .23569 \\
\hline
\end{tabular}

monthly values. The input used to calculate these annualto-monthly allocation factors were taken from Erickson et al. (1999).

Finally, monthly total emissions per $36-\mathrm{km}$ grid cell were allocated into a single representative day of emissions for each month with hourly values temporally allocated based on Keene et al. (2007) and Osthoff et al. (2008). The temporal allocation profile applied for $\mathrm{HCl}$ is shown in Fig. A6 while the profile applied for $\mathrm{CINO}_{2}$ is shown in Fig. A7 (these profiles were created by visual approximation from figures provided in the sources noted). The representative day of emissions created for each month was then used to represent each remaining simulation. 


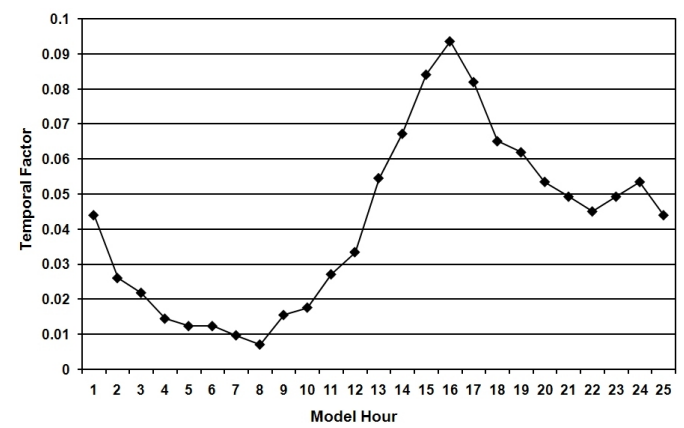

Fig. A6. Hourly temporal profile derived from the diel variability of $\mathrm{HCl}$ provided in Keene et al. (2007). This was applied to perform hourly allocations for the representative day of emissions created for oceanic $\mathrm{HCl}$.

\section{A4 $\quad \mathrm{NH}_{3}$}

Natural sources of ammonia included in this simulation were oceans, wild animals, and wildfires. The role of soils as a source of $\mathrm{NH}_{3}$ is described in the main paper along with the methodology for treating wildfires. The method of estimating natural emissions of $\mathrm{NH}_{3}$ from wild animals was based on the work described by Mansell (2005). The CMU Ammonia Model version 3.6 (Davidson et al., 2004) was used to estimate the total wild animal $\mathrm{NH}_{3}$ emissions from the contiguous US. The CMU model was ran with the inherent activity data (used "as-is" with no modifications or additional quality assurance) and emission factors for bears, deer, and elk. Emissions factors from the CMU model are provided in Table A5. The resulting annual total $\mathrm{NH}_{3}(\mathrm{~kg})$ emissions by county from the CMU Model run were then spatially allocated to counties using a GIS so that subsequent allocations to model grid cells could be performed. The wild animal emissions were considered temporally invariant in our work in agreement with work by both Davidson et al. (2004) and Mansell (2005). The guidance taken from Mansell (2005) used forest, grass, and shrubland to spatially allocate the wild animal $\mathrm{NH}_{3}$. However, given that our modeling assumes only natural land cover exists within the modeling domain, spatial allocation to these three types was not performed. Instead, county level resolution emissions were deemed sufficient and the annual total emissions were allocated based on the fraction of county in each modeling grid cell. These gridded annual emissions were subsequently converted to an hourly emissions file for one representative day with no hourly variation, consistent with the temporal invariance assumption. Subsequently, a prototypical day was replicated to represent all days of the year.

Canadian wild animal emissions were estimated slightly differently. We determined animal populations (activity) and their native ranges, known habitat boundaries, or areas considered as wild land areas suitable for habitation and then allocated these populations to the habitats. These values

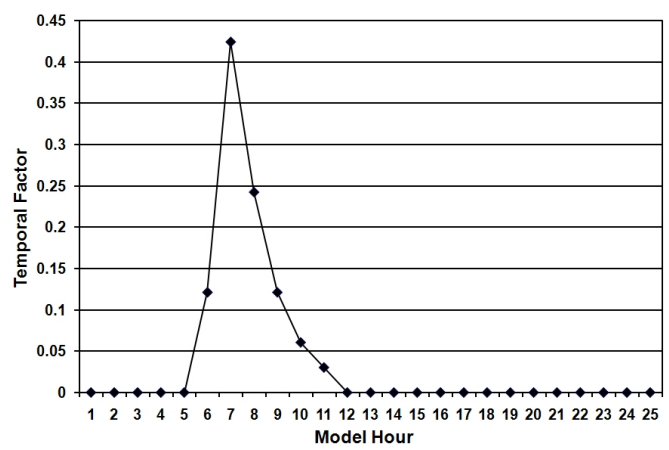

Fig. A7. Hourly temporal profile derived from the diel variability of $\mathrm{ClNO}_{2}$ provided in Osthoff et al. (2008). This was applied to perform hourly allocations for the representative day of emissions created for oceanic $\mathrm{ClNO}_{2}$. NOTE: See caveat mentioned in our conclusions.

Table A5. CMU Ammonia Model v3.6 wild animal emissions factors.

\begin{tabular}{lc}
\hline Source & Emission Factor $\mathrm{kg} \mathrm{NH}_{3}$ per animal $\left.\mathrm{yr}^{-1}\right)$ \\
\hline Bear (Black \& Grizzly) & 0.378 \\
Deer & 0.378 \\
Elk & 2.04 \\
\hline
\end{tabular}

were allocated to the modeling grid cells using GIS software. Animal population emissions factors were temporally allocated in the same invariant manner as in the US. Canadian activity data for whitetail and mule deer, black and grizzly bear, elk, and moose were acquired for British Columbia from the British Columbia Ministry of Environment, Lands and Parks 2000-2001 publications. The CMU Model emission factor for elk (Table A5) was used as the surrogate emission factor for moose. Activity data for the remaining Canadian provinces within our modeling domain (Alberta, Saskatchewan, Manitoba, Ontario, Quebec, New Brunswick, and Nova Scotia) were not as well documented. However, estimated populations were obtained as possible and are shown by Canadian province in Table A6. A habitat surrogate factor was created for these remaining provinces based on the BELD3 aggregated allocations of forest, grassland, and shrubland for our modeling domain grid cells. This habitat (i.e. wild land) surrogate factor was applied to the species-specific native range to allocate animal populations within this native range to each modeling grid cell. Native ranges for the wild animals modeled came from Patterson et al. (2007) except for the elk range in Manitoba which was available from the Manitoba Wildlife and Ecosystem Protection Branch over the Internet (http://www.gov.mb.ca/ conservation/wildlife/mbsp/fs/elk.html).

There is limited information on Mexican animal populations. Thus, we used the GEIA wild animal $\mathrm{NH}_{3}$ emissions 
Table A6. Populations of Canadian wild animals ${ }^{\mathrm{a}}$.

\begin{tabular}{lcccccc}
\hline Province & White-tail Deer & Mule Deer & Moose & Elk & Black Bear & Grizzly Bear \\
\hline Alberta $^{\mathrm{b}}$ & 232,000 & 133,000 & 118,000 & 26,000 & 40,000 & 500 \\
Saskatchewan $^{\mathrm{c}}$ & 369,263 & 43,028 & 43,196 & 14,782 & 35,000 & N/A \\
Manitoba $^{\mathrm{d}}$ & $250,000^{\mathrm{e}}$ & N/A & 32,000 & 7,000 & 27,500 & N/A \\
Ontario $^{\mathrm{f}, \mathrm{g}}$ & 400,000 & N/A & 200,000 & N/A & 70,000 & N/A \\
Quebec $^{\mathrm{g}, \mathrm{h}}$ & $285,000^{\mathrm{i}}$ & N/A & 125,000 & N/A & 60,000 & N/A \\
New Brunswickj $\mathrm{j}, \mathrm{k}$ & 85,000 & N/A & 25,000 & N/A & 12,500 & N/A \\
Nova Scotia $^{\mathrm{g}, \mathrm{l}}$ & 60,000 & N/A & 9,000 & N/A & 3,000 & N/A \\
\hline
\end{tabular}

a Caribou, antelope, and other ungulate populations are not included in the population estimates. N/A=population estimates not acquired/available at the time of this modeling or data not found for native ranges.

b Government of Alberta Sustainable Resource Development website has since been modified; however, original source is archived and viewable at: http://web.archive.org/web/20080603222931/www.srd.gov.ab.ca/fishwildlife/livingwith/huntingalberta/gamespecies.aspx, http://web.archive.org/web/20071103182904/www.srd.gov.ab.ca/fishwildlife/wildlifeinalberta/bearsalberta/presentstatus.aspx, accessed: 12 January 2010.

c Status and management of Wildlife in Saskatchewan: 2002 and 2003 Resource Technical Report: 2005-2. Saskatchewan Environment Resource Stewardship Branch website has since been modified; however, original source is archived and viewable at: http: //web.archive.org/web/20060212185403/www.se.gov.sk.ca/fishwild/Status+of+Wildlife+2002-03.pdf, accessed: 12 January 2010.

d Manitoba Conservation Wildlife and Ecosystem Protection Branch website has since been modified; however, original source is archived and viewable at: http://web.archive.org/web/20050321140253/www.gov.mb.ca/conservation/wildlife/managing/, accessed: 12 January 2010 .

e 1995 historic peak.

${ }^{\mathrm{f}}$ Ontario Natural Resources Information Center (2006).

g US Geological Survey Biology website has since been modified; however, original source is archived and viewable at: http://web.archive. org/web/20070715151620/http://biology.usgs.gov/s+t/noframe/c286.htm, accessed: 12 January 2010.

h Quebec Ministry for the Natural Resources and Fauna (2006).

i Mainland population.

j New Brunswick Department of Natural Resources (2006).

k North American Bear Center website has since been modified; however, original source is archived and viewable at: http://web.archive. org/web/20071121142706/http://www.bear.org/Black/BlackBearPopulations.html, accessed: 12 January 2010.

${ }^{1}$ Nova Scotia Wildlife Division (2006).

data set spatially allocating the GEIA $1^{\circ} \times 1^{\circ}$ global dataset to the $36 \times 36 \mathrm{~km}$ resolution grid cells. Wild animal $\mathrm{NH}_{3}$ emissions provided within the GEIA database are actually based on the 1990 estimates from the EDGAR 2.0 database. Annual totals from the GEIA grid were allocated to the modeling domain and handled in a similar fashion to that done for US wild animal emissions.

Natural emissions of $\mathrm{NH}_{3}$ from ocean surfaces within the modeling domain were included based on annual ocean $\mathrm{NH}_{3}$ emissions estimates from the GEIA database. These were allocated to grid cells based on percent area of ocean per grid cell using a GIS. Emissions were directly allocated temporally from annual values to a daily value assuming no seasonal differences. This seasonal invariance is based on the SMOKE v2.5 monthly temporal profile for salt water allocation. Hourly temporal variation was derived by applying the SMOKE v2.5 temporal profile for salt water to the daily total emissions. Temporal profiles are shown in Fig. A4. Ocean $\mathrm{NH}_{3}$ emissions were created for a single representative day and this representative day was used for the remaining days of the year.
Acknowledgements. The authors are grateful to Elizabeth Bailey, Jimmie Kelsoe, Qi Mao, and Jon Mallard for their contributions to the research and computations involved in this work. We would also like to thank Lesley Ott (UMBC/GEST, Greenbelt, MD) for her guidance and support in the determination of methods for simulating lightning $\mathrm{NO}_{\mathrm{x}}$ and Gerard Mansell (ENVIRON International Corporation, Novato, CA) for the datasets, guidance, and support he provided in the determination of methods for simulating wild animal $\mathrm{NH}_{3}$ and windblown dust. We are also grateful to James Boylan (Georgia Department of Natural Resources, Atlanta, GA) and Cyndi Loomis (Alpine Geophysics, Arvada, CO) for providing the anthropogenic emission inventories as well as Sheryl McCrary and John Cramer (VAISALA Inc., Tucson, AZ) for support and guidance on the NLDN data. This study was supported through research funds from the Electric Power Research Institute (EPRI) and the TVA Environmental Research Program.

Edited by: M. Kanakidou 


\section{References}

Andreae, M. O. and Jaeschke, W. A.: Exchange of Sulphur between Biosphere and Atmosphere over Temperate and Tropical Regions, in: Sulphur Cycling on the Continents: Wetlands, terrestrial ecosystems, and associated water bodies, SCOPE 48, edited by: Howarth, R. W., Stewart, J. W. B., and Ivanov, M. V., pp. 27-61, John Wiley and Sons, New York, NY, 1992.

Athanasopoulou, E., Tombrou, M., Pandis, S. N., and Russell, A. G.: The role of sea-salt emissions and heterogeneous chemistry in the air quality of polluted coastal areas, Atmos. Chem. Phys. Discuss., 8, 3807-3841, doi:10.5194/acpd-8-3807-2008, 2008.

Atkinson, R., Baulch, D. L., Cox, R. A., Crowley, J. N., Hampson, R. F., Hynes, R. G., Jenkin, M. E., Rossi, M. J., and Troe, J.: Evaluated kinetic and photochemical data for atmospheric chemistry: Volume III - gas phase reactions of inorganic halogens, Atmos. Chem. Phys., 7, 981-1191, doi:10.5194/acp-7-981-2007, 2007.

Bates, T. S., Lamb, B. K., Guenther, A., Dignon, J., and Stoiber, R. E.: Sulfur Emissions to the Atmosphere from Natural Sources, J. Atmos. Chem., 14, 315-337, 1992.

Battye, W. and Battye, R.: Development of emissions inventory methods for wildland fire - final report, US Environmental Protection Agency, Research Triangle Park, NC, 82 pp, 2002.

Behnke, W., George, C., Scheer, V., and Zetzsch, C.: Production and decay of $\mathrm{ClNO}_{2}$ from the reaction of gaseous $\mathrm{N}_{2} \mathrm{O}_{5}$ with $\mathrm{NaCl}$ solution: bulk and aerosol experiments, J. Geophys. Res., 102(D3), 3795-3804, 1997.

Benkovitz, C. M., Scholtz, M. T., Pacyna, J., Tarrason, L., Dignon, J., Voldner, E. C., Spiro, P. A., Logan, J. A., and Graedel, T. E.: Global gridded inventories of anthropogenic emissions of sulfur and nitrogen, J. Geophys. Res., 101(D22), 29239-29253, 1996.

Berresheim, H. and Jaeschke, W. A.: The contribution of volcanoes to the global atmospheric sulfur budget, J. Geophys. Res., 88(C6), 3732-3740, 1983.

Boccippio, D. J., Cummins, K. L., Christian, H. J., and Goodman, S. J.: Combined Satellite- and Surface-Based Estimation of the Intracloud - Cloud-to-Ground Lightning Ratio over the Continental United States, Mon. Weather Rev., 129, 108-122, 2001.

Bodenbender, J., Wassmann, R., Papen, H., Rennenberg, H.: Temporal and spatial variation of sulfur-gas-transfer between coastal marine sediments and the atmosphere, Atmos. Environ., 33, 3487-3502, 1999.

Bouwman, A. F., Lee, D. S., Asman, W. A. H., Dentener, F. J., Vanderhoek, K. W., and Olivier, J. G. J.: A global highresolution emission inventory for ammonia, Global Biogeochem. Cy., 11(4), 561-587, 1997.

Byun, D. and Schere, K. L.: Review of the governing equations, computational algorithms, and other components of the Models3 Community Multiscale Air Quality (CMAQ) Modeling System, Appl. Mech. Rev., 59, 51-77, 2006.

Chameides, W., Lindsay, R., Richardson, J., and Kiang, C.: The role of biogenic hydrocarbons in urban photochemical smog: Atlanta as a case study, Science, 241, 1473-1475, 1988.

Chang, S. and Allen, D. T.: Chlorine chemistry in urban atmospheres: aerosol formation associated with anthropogenic chlorine emissions in southeast Texas, Atmos. Environ., 40, doi:10.1016/j.atmosenv.2006.04.070, 2006.

Chin, M., Ginoux, P., Kinne, S., Holben, B. N., Duncan, B. N., Martin, R. V., Logan, J. A., Higurashi, A., and Nakajima, T.: Tropo- spheric aerosol optical thickness from the GOCART model and comparisons with satellite and sunphotometer measurements, J. Atmos. Sci., 59, 461-483, 2002.

Choi, Y. and Fernando, H. J. S.: Implementation of a windblown dust parameterization into MODELS-3/CMAQ: Application to episodic PM events in the US/Mexico border, Atmos. Environ., 42, 6039-6046, 2008.

Clarke, A. D., Owens, S. R., and Zhou, J.: An ultrafine sea salt flux from breaking waves: implications for cloud condensation nuclei in the remote marine atmosphere, J. Geophys. Res., 111, D06202, doi:10.1029/2005JD006565, 2006.

CMAS, Sparse Matrix Operators Kernel Emissions model (SMOKE) version 2.5, University of North Carolina at Chapel Hill Institute for the Environment, Center for Environmental Modeling for Policy Development (CEMPD), Community Modeling and Analysis System Center (CMAS), Chapel Hill, NC (http://www.smoke-model.org), 2008.

Cooke, W. F., Liousse, C., Cachier, H., and Feichter, J.: Construction of a $1^{\circ} \times 1^{\circ}$ fossil fuel emission data set for carbonaceous aerosol and implementation and radiation impact in the ECHAM-4 model, J. Geophys. Res., 104, 22137-22162, 1999.

Davidson, C., Adams, P., Strader, R., Pinder, R., Anderson, N., Goebes, M., and Ayers, J.: CMU Ammonia Model Version 3.6 (http://www.cmu.edu/ammonia/), last access: 8 May 2007, 2004.

DeCaria, A. J., Pickering, K. E., Stenchikov, G. L., Scala, J. R., Stith, J. L., Dye, J. E., Ridley, B. A., and Laroche, P.: A cloudscale model study of lightning-generated $\mathrm{NO}_{\mathrm{x}}$ in an individual thunderstorm during STEREO-A, J. Geophys. Res., 105, 1160111616, 2000.

DeLaune, R. D., Devai, I., and Lindau, C. W.: Flux of Reduced Sulfur Gases Along a Salinity Gradient in Louisiana Coastal Marshes, Estuarine, Coast. Shelf Sci., 54, 1003-1011, 2002.

De Leeuw, G., Neele, F. P., Hill, M., Smith, M. H., and Vignati, E.: Production of sea spray aerosol in the surf zone, J. Geophys. Res., 105(D24), 29397-29410, 2000.

Denman, K. L., Brasseur, G., Chidthaisong, A., Ciais, P., Cox, P. M., Dickinson, R. E., Hauglustaine, D., Heinze, C., Holland, E., Jacob, D., Lohmann, U., Ramachandran, S., da Silva Dias, P. L., Wofsy, S. C., and Zhang, X.: Couplings Between Changes in the Climate System and Biogeochemistry, in: Climate Change 2007: The Physical Science Basis. Contribution of Working Group I to the Fourth Assessment Report of the Intergovernmental Panel on Climate Change, edited by: Solomon, S., Qin, D., Manning, M., Chen, Z., Marquis, M., Averyt, K. B., Tignor, M. and Miller, H. L., Cambridge University Press, Cambridge, United Kingdom, 2007.

ENVIRON: User's Guide to the Comprehensive Air Quality Model with Extensions (CAMx), version 4.10s, ENVIRON International Corp., Novato, CA (http://www.camx.com), last access: 29 October 2004, 2004.

Erickson III, D. J., Keene, W. C., and Gong, S. L.: A general circulation model based calculation of $\mathrm{HCl}$ and $\mathrm{ClNO} 2$ production from sea salt dechlorination: Reactive Chlorine Emissions Inventory, J. Geophys. Res., 104(D7), 8347-8372, 1999.

Finlayson-Pitts, B. J. and Pitts Jr., J. N.: Chemistry of the Upper and Lower Atmosphere, Academic Press, San Diego, 2000.

Giblin, A. E. and Wieder, R. K.: Sulphur cycling in marine and freshwater wetlands in Sulphur Cycling on the Continents: Wetlands, terrestrial ecosystems, and associated water bodies, 
SCOPE 48, edited by: Howarth, R. W. and Stewart, J. W. B., and Ivanov, M.V., pp 85-117, John Wiley and Sons, New York, NY, 1992.

Gong, S. L.: A parameterization of sea salt aerosol source function for sub- and super-micron particles, Global Biogeochem. Cy, 17(4), (8-)1-(8-)6, 2003.

Granier, C., Guenther, A., Lamarque, J.F., Mieville, A., Muller, J. F., Olivier, J., Orlando, J., Peters, J., Petron, G., Tyndall, G., and Wallens, S.: POET, a database of surface emissions of ozone precursors (http://www.aero.jussieu.fr/projet/ACCENT/POET.php), last access: 24 May 2010, 2005.

Gröne, T.: Volatile organic sulfur species in three North Italian lakes: seasonality, possible sources and flux to the atmosphere, Mem. Ist. ital. Idrobiol., 56, 77-94, 1997.

Guenther, A., Geron, C., Pierce, T., Lamb, B., Harley, P., and Fall, R.: Natural emissions of non- methane volatile organic compounds, carbon monoxide, and oxides of nitrogen from North America, Atmos. Environ., 34, 2205-2230, 2000.

Guenther, A., Karl, T., Harley, P., Wiedinmyer, C., Palmer, P. I., and Geron, C.: Estimates of global terrestrial isoprene emissions using MEGAN (Model of Emissions of Gases and Aerosols from Nature), Atmos. Chem. Phys., 6, 3181-3210, doi:10.5194/acp-63181-2006, 2006.

Hao, W. M. and Piu, M.-H.: Spatial distribution of tropical biomass burning in 1980 with $5^{\circ} \times 5^{\circ}$ resolution, Global Biogeochem. Cy., 8, 495-503, 1994.

Heald, C. L., Jacob, D. J., Park, R. J., Alexander, B., Fairlie, T. D., Yantosca, R. M., and Chu, D. A.: Transpacific transport of Asian anthropogenic aerosols and its impact on surface air quality in the United States, J. Geophys. Res., 111, D14310, doi:10.1029/2005JD006847, 2006.

Helmig, D., Ortega, J., Duhl, T., Tanner, D., Guenther, A., Harley, P., Wiedinmyer, C., Milford, J., and Sakulyanontvittaya, T.: Sesquiterpene emissions from pine trees- Identifications, emission rates and flux estimates for the contiguous United States, Environ. Sci. Technol., 41, 1545-1553, 2007.

Holler, H. and Schumann, U.: EULINOX (European Lightning Nitrogen Oxides Project) Final Report, http://www.pa. op.dlr.de/eulinox/publications/finalrep/index.html, last access: 24 May 2010, 2000.

Hudman, R. C., Jacob, D. J., Turquety, S., Leibensperger, E. M., Murray, L. T., Wu, S., Gilliland, A. B., Avery, M., Bertram, T. H., Brune, W., Cohen, R. C., Dibb, J. E., Flocke, F. M., Fried, A., Holloway, J., Neuman, J. A., Orville, R., Perring, A., Ren, X., Sachse, G. W., Singh, H. B., Swanson, A., and Wooldridge, P. J.: Surface and lightning sources of nitrogen oxides over the United States: Magnitudes, chemical evolution, and outflow, J. Geophys. Res., 112, D12S05, doi:10.1029/2006JD007912, 2007.

Kaminski, J. W., Neary, L., Struzewska, J., McConnell, J. C., Lupu, A., Jarosz, J., Toyota, K., Gong, S. L., Côté, J., Liu, X., Chance, K., and Richter, A.: GEM-AQ, an on-line global multiscale chemical weather system: model description and evaluation of gas phase chemistry processes, Atmos. Chem. Phys. Discuss., 7, 14895-14937, doi:10.5194/acpd-7-14895-2007, 2007.

Kaynak, B., Hu, Y., Martin, R. V., Russell, A. G., Choi, Y., and Wang, Y.: The effect of lightning $\mathrm{NO}_{\mathrm{x}}$ production on surface ozone in the continental United States, Atmos. Chem. Phys., 8, 5151-5159, doi:10.5194/acp-8-5151-2008, 2008.

Keene, W. C., Stutz, J., Pszenny, A. A. P., Maben, J. R., Fischer,
E. V., Smith, A. M., Glasow, R., Pechtl, S., Sive, B. C., and Varner, R. K.: Inorganic chlorine and bromine in coastal New England air during summer, J. Geophys. Res., 112(D10S12), doi:10.1029/2006JD007689, 2007.

Kettle, A. J., Andreae, M. O., Amouroux, D., Andreae, T. W., Bates, T. S., Berresheim, H., Bingemer, H., Boniforti, R., Curran, M. A J., DiTullio, G. R., Helas, G., Jones, G. B., Keller, M. D., Kiene, R. P., Leck, C., Levasseur, M., Malin, G., Maspero, M., Matrai, P., McTaggart, A. R., Mihalopoulos, N., Nguyen, B. C., Novo, A., Putaud, J. P., Rapsomanikis, S., Roberts, G., Schebeske, G., Sharma, S., Simó, R., Staubes, R., Turner, S., and Uher, G.: A global database of sea surface dimethylsulfide (DMS) measurements and a procedure to predict sea surface DMS as a function of latitude, longitude and month, Global Biogeochem. Cy., 13(2), 399-444, 1999.

Kettle, A. J. and Andreae, M. O.: Flux of dimethylsulfide from the oceans: A comparison of updated data sets and flux models, J. Geophys. Res., 105(D22), 26793-26808, 2000.

Kinnee, E., Geron, C., and Pierce, T.: United States land use inventory for estimating biogenic ozone precursor emissions, Ecol. Appl., 7(1), 46-58, 1997.

Kloster, S., Feichter, J., Maier-Reimer, E., Six, K. D., Stier, P., and Wetzel, P.: DMS cycle in the marine ocean-atmosphere system a global model study, Biogeosciences, 3, 29-51, doi:10.5194/bg3-29-2006, 2006.

Knipping, E. M., and D. Dabdub, D.: Impact of chlorine emissions from sea salt aerosol on coastal urban ozone, Environ. Sci. Technol., 37, 275-284, 2003.

Koo, B., Chien, C.-J., Tonnesen, G., Morris, R., Johnson, J., Sakulyanontvittaya, T., Piyachaturawat, P., and Yarwood, G.: Natural emissions for regional modeling of background ozone and particulate matter and impacts on emissions control strategies, Atmos. Environ., doi:10.1016/j.atmosenv.2010.02.041, 2010.

Kreidenweis, S. M., Penner, J. E., Yi, F., and Seinfeld, J. H.: The effects of dimethylsulfide upon marine aerosol concentrations, Atmos. Environ., 25A, 2501-2511, 1991.

MACTEC: Documentation of the Base G2 and Best \& Final 2002 Base Year, 2009 and 2018 Emission Inventories for VISTAS, Visibility Improvement State and Tribal Association of the Southeast. (http://vistas-sesarm.org/documents/ VISTABF2003-20-2008.pdf), 2008.

Mansell, G. E.: An Improved Ammonia Inventory for the WRAP Domain: Final Report: Volume I. Prepared for the Western Governors Association by ENVIRON International Corporation, Novato, CA, 2005.

Mansell, G. E., Lau, S., Russell, J., and Omary, M.: Final Report: Fugitive Wind Blown Dust Emissions and Model Performance Evaluation, Phase II. Prepared for the Western Governors Association by ENVIRON International Corporation, Novato, CA and the University of California at Riverside Center for Environmental Research and Technology, Riverside, CA, 2006.

McGee, K. A., Doukas, M. P., and Gerlach, T. M.: Quiescent Hydrogen Sulfide and Carbon Dioxide Degassing from Mount Baker, Washington, Geophys. Res. Lett., 28(23), 4479-4482, 2001.

Morris, R. E., Koo, B., Tesche, T. W., Loomis, C., Stella, G., Tonnesen, G., and Wang, Z.: VISTAS Emissions and Air Quality Modeling - Phase I Task 6 Report: Modeling Protocol for the 
VISTAS Phase II Regional Haze Modeling: First Draft Report, jointly by ENVIRON International Corporation, Alpine Geophysics LLC, and University of California Riverside, 2004.

Müller, J.-F.: Geographical distribution and seasonal variation of surface emissions and deposition velocities of atmospheric trace gases, J. Geophys. Res., 97, 3787-3804, 1992.

NAPAP: Emissions Involved in Acidic Deposition Processes, Report 1. In Acid Deposition: State of Science and Technology, Irving P.M., Ed., Vol. 1, Emissions, Atmospheric Processes, and Deposition, Office of the Director, Washington, DC, 81-109, 1991.

National Research Council (NRC): Acid Deposition - Atmospheric Processes in Eastern North America, J. Calvert, Chairman, Committee on Atmospheric Transport and Chemical Transformation in Acid Precipitation, National Academy Press, Washington, DC, 1983.

Nesbitt, S. W., Zhang, R., and Orville, R. E.: Seasonal and global $\mathrm{NO}_{\mathrm{x}}$ production by lightning estimated from the Optical Transient Detector (OTD), Tellus B, 52, 1206-1215. doi:10.1034/j.1600-0889.2000.01121.x, 2000.

Novak, J. H. and Pierce, T. E.: Natural emissions of oxidant precursors, Water Air Soil Poll., 67, 57-77, 1993.

Olivier, J. G. J, Berdowski, J. J. M., Peters, J. A. H. W., Bakker, J., Visschedijk, A. J. H., and Bloos, J. J.: Applications of EDGAR Including a description of EDGAR 3.2: reference database with trend data for 1970-1995. RIVM report 773301001/NRP report 410200 051, RIVM, Bilthoven, The Netherlands, 2002.

Orville, R. E., Huffines, G. R., Burrows, W. R., Holle, R. L., and Cummins, K. L.: The North American Lightning Detection Network (NALDN) - First Results: 1998-2000, Mon. Weather Rev., 130, 2098-2109, 2002.

Osthoff, H. D., Roberts, J. M., Ravishankara, A. R., Williams, E. J., Lerner, B. M., Sommariva, R., Bates, T. S., Coffman, D., Quinn, P. K., Dibb, J. E., Stark, H., Burkholder, J. B., Talukdar, R. K., Meagher, J., Fehsenfeld, F. C., and Brown, S. S.: High levels of nitryl chloride in the polluted subtropical marine boundary layer, Nat. Geosci., 1, 324-328, 2008.

Ott, L., Pickering, K., Stenchikov, G., Huntreiser, H., and Schumann, U.: Effects of lightning NOx production during the 21 July European Lightning Nitrogen Oxides Project storm studied with a three-dimensional cloud-scale chemical transport model, J. Geophys. Res., 112, D05307, doi:10.1029/2006JD007365, 2007.

Ott, L., Pickering, K., Stenchikov, G., Allen, D., DeCaria, A., Ridley, B., Ruei-Fong, L., Lang, S., Wei-Kuo, T.: Production of lightning $\mathrm{NO}_{\mathrm{x}}$ and its vertical distribution calculated from 3-D cloud-scale chemical transport model simulations, J. Geophys. Res., in press, 2010.

Park, R. J., Jacob, D. J., Chin, M., and Martin, R. V.: Sources of carbonaceous aerosols over the United States and implications for natural visibility, J. Geophys. Res., 108(D12), 4355, doi:10.1029/2002JD003190, 2003.

Park, R. J., Jacob, D. J., Field, B. D., Yantosca, R. M., and Chin, M.: Natural and transboundary pollution influences on sulfate-nitrate-ammonium aerosols in the United States: implications for policy, J. Geophys. Res., 109, D15204, doi:10.1029/2003JD004473, 2004.

Park, R. J., Jacob, D. J., Kumar, N., and Yantosca, R. M.: Regional visibility statistics in the United States: Natural and transboundary pollution influences, and implications for the Regional Haze Rule, Atmos. Environ., 40(28), 5405-5423, 2006.
Patterson, B. D., Ceballos, G., Sechrest, W., Tognelli, M. F., Brooks, T., Luna, L., Ortega, P., Salazar, I., and Young, B. E.: Digital Distribution Maps of the Mammals of the Western Hemisphere, version 3.0. NatureServe, Arlington, Virginia, USA, 2007.

Pickering, K. E., Wang, Y., Tao, W.-K., Price, C., Müller, J.-F.: Vertical distributions of lightning $\mathrm{NO}_{\mathrm{x}}$ for use in regional and global chemical transport models, J. Geophys. Res., 103(D23), 31203-31216, 1998.

Pickering, K. E., Ott, L., Allen, D., DeCaria, A., Stenchikov, G., and Tao, W. K.: Improving lightning $\mathrm{NO}_{\mathrm{x}}$ parameterizations for global chemical transport models, Second Conference on Meteorological Applications of Lightning Data, American Meteorological Society, Atlanta, GA, 2006.

Pierce, T.: Importance of Lightning NO for Regional Air Quality Modeling. Presented at the Global Hydrology and Climate Center, Huntsville, Alabama, October 20, 1999.

Pierce, T., Benjey, W., Ching, J., Gillette, D., Gilliland, A., He, S., Mebust, M., and Pouliot, G.: Advances in Emissions Modeling of Airborne Substances, presented at the 12th Annual International Emission Inventory Conference, April 29-May 1, San Diego, Ca, http://www.epa.gov/ttn/chief/conference/ei12/poster/ pierce.pdf, last access: 24 May 2010, 2003.

Price, C. and Rind, D.: What determines the cloud-to-ground lightning fraction in thunderstorms?, Geophys. Res. Lett, 20(6), 463 466, 1993.

Price, C., Penner, J., and Prather, M.: $\mathrm{NO}_{\mathrm{x}}$ from lightning 1. Global distribution based on lightning physics, J. Geophys. Res., 102, 5929-5941, 1997.

Richards, S. R., Kelly, C. A., and Rudd, J. W. M.: Organic volatile sulfur in lakes of the Canadian Shield and its loss to the atmosphere, Limnol. Oceanogr., 36, 468-482, 1991.

Richards, S. R., Rudd, J. W. M., and Kelly, C. A.: Organic volatile sulfur in lakes ranging in sulfate and dissolved salt concentration over five orders of magnitude, Limnol. Oceanogr., 39(3), 562$572,1994$.

Sakulyanontvittaya, T., Duhl, T., Wiedinmyer, C., Helmig, D., Matsunaga, S., Potosnak, M., Milford, J., and Guenther, A. Monoterpene and sesquiterpene emission estimates for the United States, Environ. Sci. Technol., 42, 1623-1629, 2008.

Sharma, S., Barrie, L. A., Hastie, D. R., and Kelly, C.: Dimethyl sulfide emissions to the atmosphere from lakes of the Canadian boreal region, J. Geophys. Res., 104(D9),11585-11592, 1999.

Sherrod, D. R., Scott, W. E., and Stauffer, P. H.: A volcano rekindled; the renewed eruption of Mount St. Helens, 2004-2006: U.S. Geological Survey Professional Paper 1750, 856 p. and DVDROM (http://pubs.usgs.gov/pp/1750/), last access: 24 May 2010, 2008.

Sillman, S.: The relation between ozone, $\mathrm{NO}_{\mathrm{x}}$ and hydrocarbons in urban and polluted rural environments, Atmos. Environ., 33(12), 1821-1845, 1999.

Steudler, P. A. and Peterson, B. J.: Annual Cycle of Gaseous Sulfur Emissions from a New England Spartina Alterniflora Marsh, Atmos. Environ., 19(9), 1411-1416, 1985.

Sudo, K., Takahashi, M., Kurokawa, J., and Akimoto, H.: CHASER: a global model of the troposphere 1. model description, J. Geophys. Res., 107(D17), 4339, doi:10.1029/2001JD001113, 2002.

Tanaka, P. L., Allen, D. T., McDonald-Buller, E. C., Chang, S., Kimura, Y., Mullins, C. B., Yarwood, G., and Neece, J. D.: 
Development of a chlorine mechanism for use in the carbon bond IV chemistry model, J. Geophys. Res., 108(D4), 4145, doi:10.1029/2002JD002432, 2003a.

Tanaka, P. L., Riemerc, D. D., Chang, S., Yarwood, G., McDonaldBullera, E. C., Apel, E. C., Orlando, J. J., Silva, P. J., Jimenez, J. L., Canagaratna, M. R., Neece, J. D., Mullins, C. B., and Allen, D. T.: Direct evidence for chlorine-enhanced urban ozone formation in Houston, Texas, Atmos. Environ., 37, 1393-1400, $2003 \mathrm{~b}$.

Tesche, T. W., Morris, R., Tonnesen, G., McNally, D., Boylan, J., and Brewer, P.: CMAQ/CAMx annual 2002 performance evaluation over the eastern US, Atmos. Environ., 40, 4906-4919, 2006.

Thornton, J. A., Kercher, J. P., Riedel, T. P., Wagner, N. L., Cozic, J., Holloway, J. S., Dub'e, W. P., Wolfe, G. M., Quinn, P. K., Middlebrook, A. M., Alexander, B., and Brown, S. S.: A large atomic chlorine source inferred from mid-continental reactive nitrogen chemistry, Nature, 464, 271-274, doi:10.1038/nature08905, 2010 .
Tonnesen, G., Omary, M., Wang, Z., Jung, C. J., Morris, R., Mansell, G., Jia, Y., Wang, B., and Adelman, Z.: Report for the Western Regional Air Partnership Regional Modeling Center, University of California Riverside, Riverside, CA, (http://pah.cert.ucr.edu/aqm/308/reports/ final/2006/WRAP-RMC_2006_report_FINAL.pdf), last access: 24 May 2010, 2006.

Wang, Y., Jacob, D.J., and Logan, J.A.: Global simulation of tropospheric $\mathrm{O}_{3}-\mathrm{NO}_{\mathrm{x}}$-hydrocarbon chemistry, 1, Model formulation, J. Geophys. Res., 103, 10713-10725, 1998. 